\title{
Highly substituted benzannulated cyclooctanol derivatives by samarium diiodide-induced cyclizations
}

\author{
Jakub Saadi, Irene Brüdgam§ and Hans-Ulrich Reissig*
}

\section{Full Research Paper}

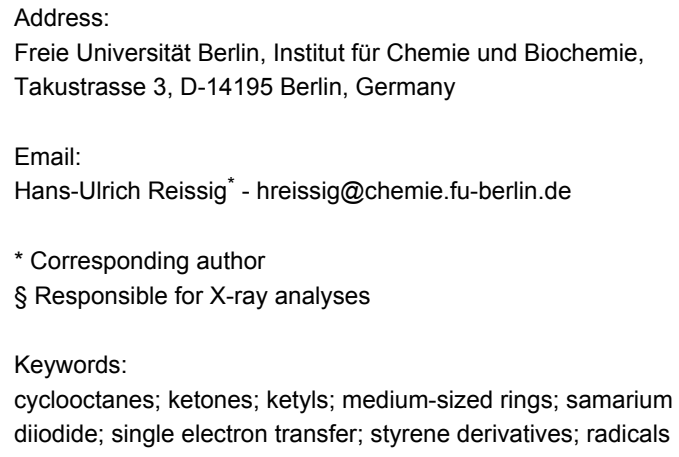

\author{
Beilstein J. Org. Chem. 2010, 6, 1229-1245. \\ doi:10.3762/bjoc.6.141 \\ Received: 18 August 2010 \\ Accepted: 11 November 2010 \\ Published: 28 December 2010 \\ Associate Editor: J. Murphy \\ (C) 2010 Saadi et al; licensee Beilstein-Institut. \\ License and terms: see end of document.
}

\begin{abstract}
A series of $\gamma$-oxo esters suitably substituted with various styrene subunits was subjected to samarium diiodide-induced 8-endo-trig cyclizations. Efficacy, regioselectivity and stereoselectivity of these reactions via samarium ketyls strongly depend on the substitution pattern of the attacked alkene moiety. The stereoselectivity of the protonation of the intermediate samariumorganyl is also influenced by the structural features of the substrates. This systematic study reveals that steric and electronic factors exhibited by the alkene and ketone subunits are of high importance for the outcome of these cyclization reactions leading to highly substituted benzannulated cyclooctanol derivatives. In exceptional cases, 7-exo-trig cyclizations to cycloheptanol derivatives have been observed. In examples with high steric hindrance the ketyl-aryl coupling can be a competing process.
\end{abstract}

\section{Introduction}

Functionalized cyclooctane substructures are frequently found in natural products and pharmacologically significant compounds. Because of their potential biological activity and intriguing geometrical features, the construction of cyclooctanoid frameworks has challenged synthetic organic chemists for a long time $[1,2]$. This task is quite challenging due to unfavourable enthalpic and entropic factors during the formation of medium-sized rings [3]. Nevertheless, in recent years a range of interesting solutions for the efficient formation of eight-membered rings has been developed [1,2,4-18]. Successful approaches include ring-closing metathesis [4], rearrangements [5], and cycloadditions [6], transition metalcatalyzed cyclizations [7,8], nucleophilic and electrophilic substitution reactions [9] as well as ring expansion reactions [10]. Among these approaches to carbocyclic compounds, samarium diiodide-mediated reactions play an important role and have been described in a number of excellent review articles [19-21] and original publications [22-35]. In our previous 
reports we have described the efficient synthesis of cyclooctanol and cyclooctenol derivatives by samarium diiodideinduced 8-endo-trig and 8-endo-dig cyclizations of $\gamma$-styryl$[20,31,33]$ and $\gamma$-phenyl-alkynyl-substituted [20,32] ketoesters. Recently, we have also reported our preliminary results on cyclizations of analogous starting materials bearing alkyl and aryl substituents at the styryl double bond, which furnished highly substituted cyclooctanol derivatives (Scheme 1) and in some cases compounds with cycloheptanol substructure [34] The transformation of A to $\mathbf{B}$ proceeds via the samarium ketyl C followed by the 8-endo-trig cyclization to D. Subsequent reduction of the radical $\mathbf{D}$ by the second equivalent samarium diiodide and protonation furnishes the cyclooctanol derivative B. The details of this mechanism have been discussed earlier [31]. This method was also successfully applied to the synthesis of cyclic compounds larger than cyclooctane derivatives [35]. Here, we would like to present our detailed results showing the scope and limitations of this method to the synthesis of highly substituted cyclooctanol derivatives and the influence of the substitution pattern of the precursors on the regioselectivity and stereochemical outcome. First, the impact on the reaction by alkyl and aryl substituents at the $\alpha$-styryl carbon of the substrates will be described, then we discuss the influence of analogous $\beta$-styryl substituents.<smiles>[R]Cc1ccccc1CC(C(C)=O)C1[R]CCC1</smiles>

A<smiles>[R2]Cc1ccccc1CC(C(C)=O)C1CCC[R1]C1O[Na]</smiles>

C

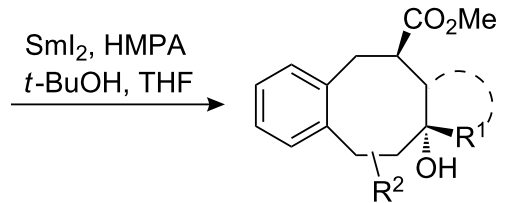

B $\uparrow \begin{aligned} & \mathrm{Sml}_{2} \\ & +t-\mathrm{BuOH}\end{aligned}$

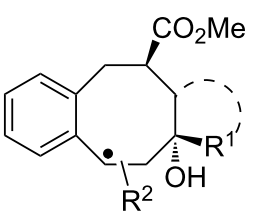

D
Scheme 1: $\mathrm{Sml}_{2}$-induced cyclizations of styryl-substituted $\mathrm{y}$-ketoesters A to benzannulated cyclooctanol derivatives B via samarium ketyl C and radical $\mathbf{D}$ (HMPA ligands at the samarium are omitted for simplicity in all Schemes, but certainly can play an important role for the outcome).

\section{Results and Discussion}

Starting materials were prepared from readily available siloxycyclopropanes in analogy to our previously described modular approach [33]. As a typical example, the synthesis of precursor 4 is depicted in Scheme 2. Cyclopropane 1 [36,37] was deproto- nated with LDA and subsequently alkylated with 2-iodobenzyl iodide, furnishing $\mathbf{2}$ in moderate yield. Intermediate $\mathbf{2}$ was then treated with triethylamine trihydrofluoride, furnishing 2-iodobenzyl-substituted $\gamma$-ketoester 3 . The following palladiumcatalyzed cross-coupling [38,39] with potassium 2-propenyl trifluoroborate afforded the cyclization precursor 4 in very good yield.
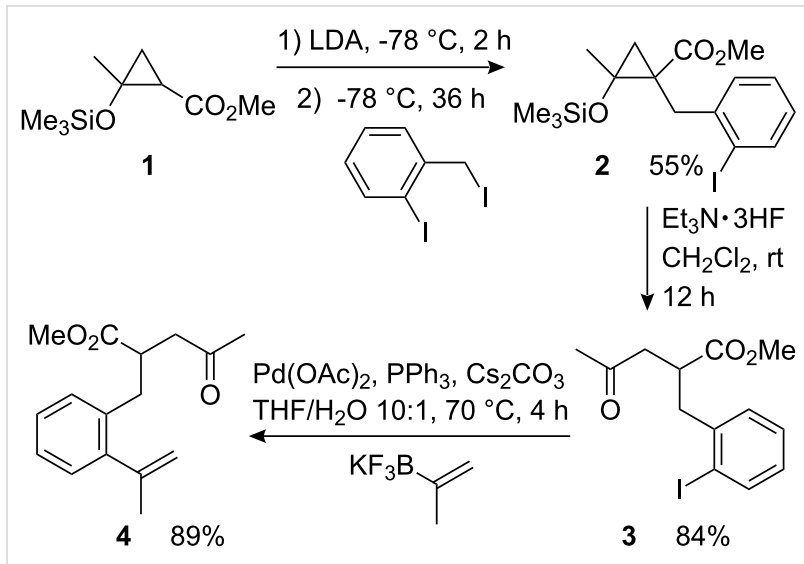

Scheme 2: Three-step synthesis of precursor 4 starting from siloxycyclopropane derivative 1.

The cyclization reactions were generally performed with 2.2 equiv of samarium diiodide in THF and in the presence of 18 equiv of HMPA and 2 equiv of tert-butanol. HMPA is crucial for the success of most of the described cyclizations because of its unique influence on the reactivity of samarium diiodide [40-44]. For control experiments and an add-on to our previous observations [33], we started our experiments with the cyclization of ketoesters $\mathbf{5 a} / \mathbf{b}$ containing a cycloheptanone subunit. Here only the unlike-configured [45] 5a furnished the expected benzannulated tricyclic compound $\mathbf{6}$ in moderate yield (Scheme 3). The like-configured precursor $\mathbf{5 b}$ is unable to arrange the reacting moieties (carbonyl group and alkene) in appropriate proximity while retaining an energetically favourable conformation of the molecule. The impact of the relative configuration of cyclic ketones as starting materials on

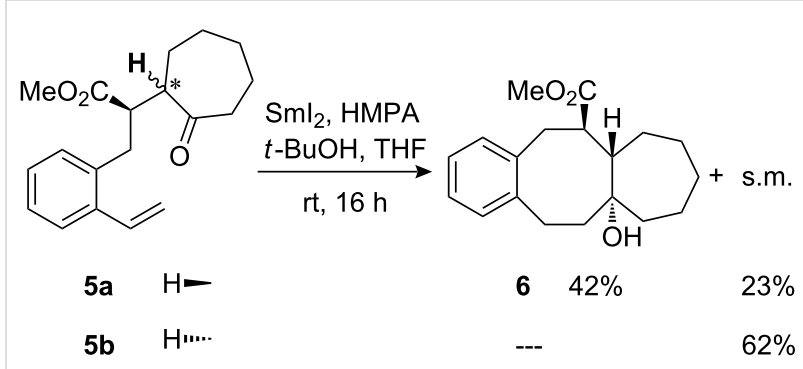

Scheme 3: Attempted cyclizations of diastereomeric cycloheptanone derivatives $\mathbf{5 a}$ and $\mathbf{5 b}$ 
the 8-endo-trig process is in full agreement with our previous observations for the corresponding cyclohexanone derivatives [33].

Because of the observed sensitivity of this reaction to steric factors, it was necessary to study the tolerance and limitations for the substitution pattern of the starting materials in more detail. At first, the influence of a methyl substituent at the $\alpha$-styryl carbon was investigated. Cyclization of the unlikeconfigured cyclohexanone derivative $7 \mathbf{a}$ afforded the expected tricyclic cyclooctanol derivative $\mathbf{8}$ in good yield and excellent trans-stereoselectivity (Scheme 4). The terms cis and trans refer in this report to the position of the methoxycarbonyl group and the hydroxyl group. In general, cis-configured products directly undergo a subsequent cyclization to the corresponding $\gamma$-lactones. It is noteworthy that the additionally introduced stereogenic centre bearing the methyl group is also generated stereoselectively.<smiles>C=C(C)c1ccccc1C[C@H](C(C)=O)[C@H]1CCCCC1=O</smiles>

$7 a$
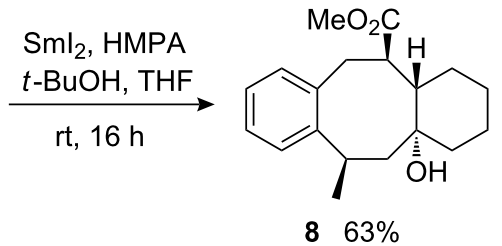

$863 \%$
Scheme 4: Samarium diiodide-induced cyclization of $\mathrm{y}$-ketoester $7 \mathrm{a}$ to tricyclic compound 8 .

In part, the configuration of $\mathbf{8}$ was assigned based on the relative configuration of the starting material. The lack of lactone formation indicates that the bridgehead hydroxyl group is trans located with respect to the methoxycarbonyl group. The configuration at the methyl-substituted stereocenter was assigned based on NOESY-correlations and careful comparison of spectroscopic data with those of related compounds. The analogous cyclopentanone-derived starting material was also tested in the cyclization reaction; however, it afforded a complex mixture of products.
Cyclization of acyclic starting material 4, bearing a methyl substituent at the $\alpha$-styryl carbon, furnished a mixture of transand cis-cyclization products $\mathbf{9}$ and $\mathbf{1 0}$ in very good combined yield, but practically no stereochemical preference. The precursor 11, bearing the more bulky iso-propyl ketone subunit, provided cyclooctanol derivatives $\mathbf{1 2}$ and $\mathbf{1 3}$ with similarly good combined yield and a clear preference for trans-product 12 (Scheme 5).

The relative configurations of lactone-bridged compounds $\mathbf{1 0}$ and $\mathbf{1 3}$ were deduced from NOESY-correlations and the assumption was confirmed that the five-membered lactone bridge, which is quite constrained and rigid, can be formed only when carboxyl and hydroxyl groups are at the same face of the eight-membered ring (Figure 1). This analysis was further supported by high similarity of NMR-spectroscopic data $\left({ }^{1} \mathrm{H}\right.$ and ${ }^{13} \mathrm{C}$ NMR shifts and relative signal patterns) with those of compound 17a and at the same time rather big differences to those of the epimeric compound $\mathbf{1 7} \mathbf{b}$.

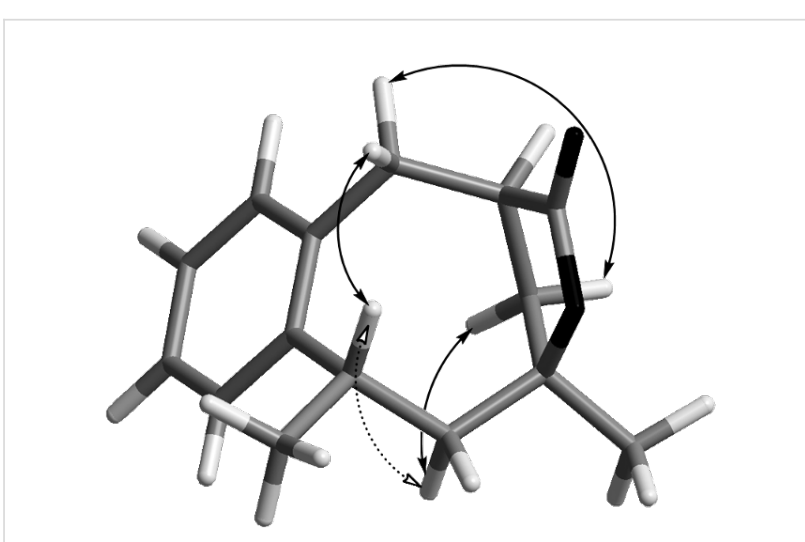

Figure 1: NOESY-correlation for compound 10.

The NOESY-experiments also indicated the proton correlations across the eight-membered ring in compounds 9 and 12. The assignment was further supported by the correlations between the protons at carbons with one substituent at the ring and their neighbouring protons. The cis-vicinal protons indicated strong<smiles>[R]C(=O)[I-][I-]=[R]</smiles>
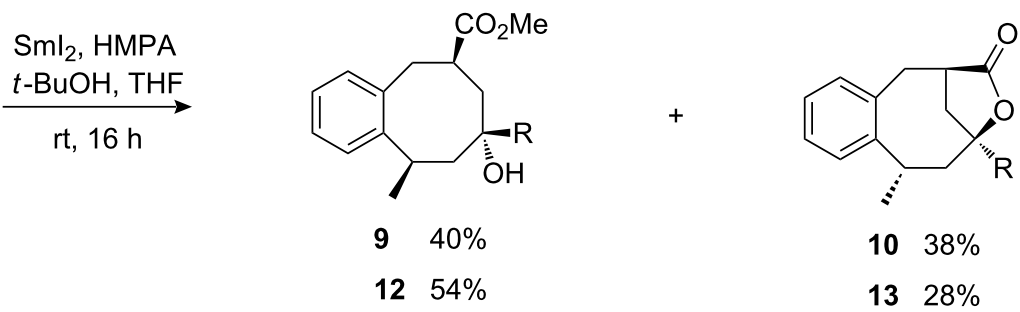

Scheme 5: Samarium diiodide-induced cyclizations of methyl ketone 4 and iso-propyl ketone 11. 
correlations, while the trans-vicinal protons, where the dihedral angle was close to $180^{\circ}$, show none or almost no correlations between each other (Figure 2).

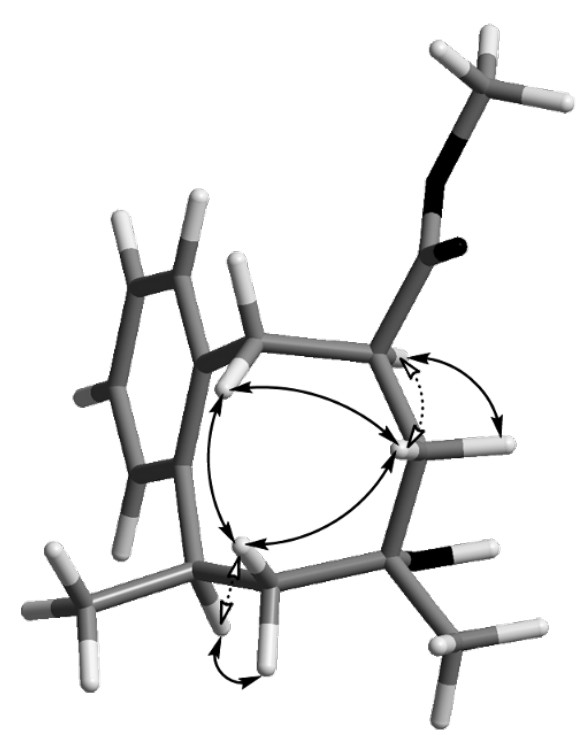

Figure 2: NOESY-correlation for compound 9.

In cyclizations of the (2-propenyl)phenyl-substituted ketoesters, trans-products are preferred; however the cis/trans stereoselectivity was generally lower than that observed for the cyclizations of their styrene analogues [33]. It seems that the previously observed correlation between the bulkiness of a ketone subunit and the increase in stereoselectivity is also effective here. This result is in accordance to the proposed eightmembered pseudo-chair-like transition structure [33], where the methoxycarbonyl group occupies a preferred pseudo-equatorial position and the ketyl substituent is competing with the bulky samariumoxy group for the other pseudo-equatorial position. Therefore, ketones with bulkier substituents preferentially react through a transition structure A (Scheme 6) leading to the transcyclization product. Remarkably, the orientation of the methyl group at the newly formed third stereogenic centre, which arises during the protonation of the samariumorganyl intermediate, was always trans to the hydroxyl group, arising from the ketone moiety. This interesting observation indicates that the protonation is highly stereoselective and the protons are coming from the same face of the ring where the samariumoxy group is situated after the completed cyclization. Since samarium(III) is very oxophilic, it is possible that the samariumoxy group coordinates tert-butanol, which is then a more acidic proton source (intermediates $\mathbf{B}$ and $\mathbf{C}$, Scheme 6). This template effect would then be responsible for the stereoselective protonation governed by the samariumoxy moiety. An intermediate similar to $\mathbf{C}$ (covalent $\mathrm{C}-\mathrm{Sm}$ bond or contact ion pair) may be a plausible alternative, which is then protonated under retention by the proton source [46].

The introduction of two additional methyl substituents between the ketone and ester moieties in the bulky diisopropyl ketone derived substrate 14, suppressed the 8-endo-trig cyclization completely and only the fragmentation product $\mathbf{1 5}$ was isolated from the reaction mixture (Scheme 7). It is not clear whether the mechanism of $\mathrm{SmI}_{2}$-induced fragmentation of 1,4-dicarbonyl compounds is of anionic or radical nature, but it has been observed in several cases $[33,47-50]$. It is possible that, due to the high steric hindrance of the initially formed samarium ketyl, the coupling to the alkene is very slow. The ketyl or the anion formed by its further reduction with $\mathrm{SmI}_{2}$ fragments to the samarium enolate of diisopropyl ketone and the radical or anion<smiles>C=C(C)c1ccccc1CC(C(C)=O)C(C)(C)C(=O)C(C)C</smiles>

14

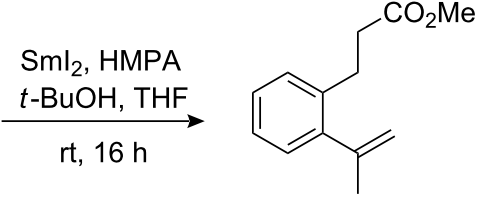

$1558 \%$
Scheme 7: Reductive fragmentation of highly hindered ketoester 14

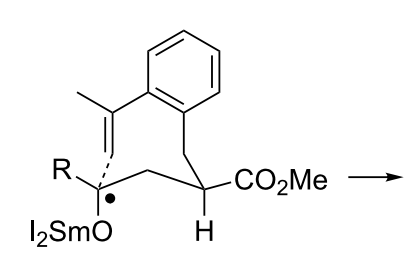

A

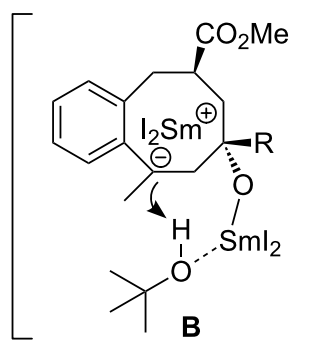

or

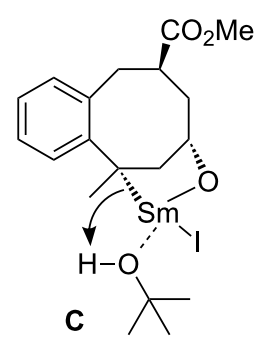

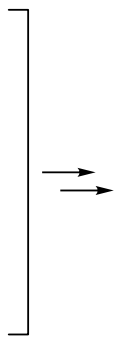<smiles>[R]C1(O)CC(C(C)=O)Cc2ccccc2C(C)C1</smiles> 
<smiles>C=C(c1ccccc1)c1ccccc1CC(CC(=O)C(C)C)C(C)C</smiles>

16
$\mathrm{Sml}_{2}, \mathrm{HMPA}$ $\stackrel{t \text {-BuOH, THF }}{\longrightarrow}$

$\mathrm{rt}, 16 \mathrm{~h}$

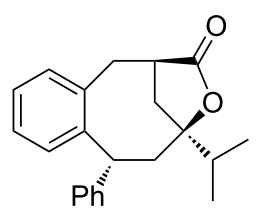

17a $37 \%$

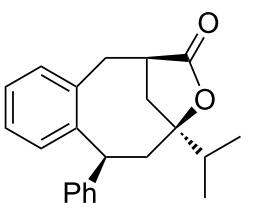

17b $22 \%$

Scheme 8: Samarium diiodide-induced cyclization of phenyl-substituted substrate 16 leading to lactones 17 a and $17 \mathbf{b}$.

stabilized by the methoxycarbonyl group. Very surprisingly in this reaction, small amounts of the $n$-propyl ester of $\mathbf{1 5}$ were also found. At this moment, the origin of the $n$-propyl group is not clear.

The modulation analysis of the electronic properties of the reacting alkene was evaluated by the introduction of a phenyl substituent to the $\alpha$-styryl position. The samarium diiodideinduced cyclization of ketoester $\mathbf{1 6}$ afforded two epimeric lactone bridged cis-products, $\mathbf{1 7} \mathbf{a}$ and $\mathbf{1 7} \mathbf{b}$, in ca. 1.7:1 ratio and in good combined yield (Scheme 8).

The relative configuration of $\mathbf{1 7} \mathbf{b}$ was unambiguously assigned by X-ray crystal structure (Figure 3) [51]. Assuming that the lactone bridge is formed only when carboxyl and hydroxyl groups are at the same face of the eight-membered ring, the configuration of $\mathbf{1 7} \mathbf{a}$ with the inverted phenyl-substituted stereocenter was assigned as the only alternative to $\mathbf{1 7} \mathbf{b}$.

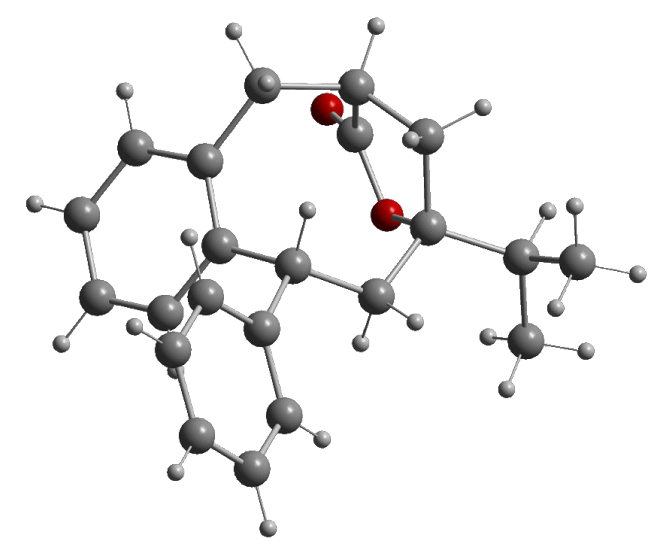

Figure 3: Molecular structure (Diamond [52]) of compound 17b

The exclusive cis-selectivity of cyclization, observed in this case, may be attributed to a high level of the steric repulsions between the bulky phenyl group at the alkene moiety and the iso-propyl group at the samarium ketyl in the usually preferred trans-transition structure (compare A, Scheme 6). It is unclear, why the protonation of the samariumorganyl species, which is additionally stabilized by the phenyl substituent, occurred with lower stereochemical preference in this case. However, if an intermediate such as $\mathbf{C}$ (Scheme 6) is also involved in this transformation a less covalent C-Sm bond may lead to a decreased stereoselectivity of the protonation step.

We have subsequently investigated the influence of alkyl substituents at the $\beta$-styryl carbon. In this series, $(E)-1$ propenyl-substituted acyclic ketones 18, 21, and $\mathbf{2 4}$ gave the expected trans-cyclooctanol derivatives 19, 22, and 25 in moderate to good yields and with excellent stereoselectivities (Scheme 9). In case of cyclization of methyl-substituted ketone 18, the side-product $\mathbf{2 0}$ was obtained as a result of a ketyl-aryl coupling [20,53-58] in addition to the desired cyclooctanol derivative 19. Also minor amounts of fragmentation product $\mathbf{2 3}$ were detected in the cyclization of ethyl ketone 21 (Scheme 9). These two observations indicate that the transition structures of the cyclizations leading to eight-membered rings are more constrained and that the reactions are slower than those where a terminally unsubstituted alkene is attacked.
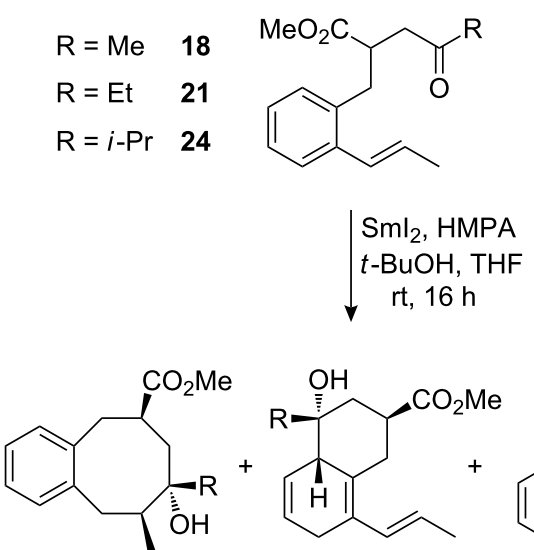<smiles>[R][C@]1(O)C[C@@H](C(C)=O)CC2=C(/C=C/C)CC=C[C@]21C</smiles>

$$
\begin{array}{lllllll}
\mathrm{R}=\mathrm{Me} & \mathbf{1 9} & 54 \% & \mathbf{2 0} & 20 \% & -- & \\
\mathrm{R}=\mathrm{Et} & \mathbf{2 2} & 56 \% & --- & & \mathbf{2 3} & 6 \% \\
\mathrm{R}=i-\operatorname{Pr} & \mathbf{2 5} & 63 \% & --- & & -- &
\end{array}
$$

Scheme 9: Samarium diiodide-induced cyclizations of $(E)$-(1propenyl)phenyl-substituted $\mathrm{y}$-ketoesters 18, 21, and 24. 
The assignment of the configuration of product $\mathbf{2 0}$ is based on that of numerous earlier described examples of $\mathrm{SmI}_{2}$-induced ketyl-aryl coupling products [57]. The configurations of products 19, 22, and 25 were assigned on the basis of NOESYcorrelations.

The transition structure for the $\mathrm{SmI}_{2}$-mediated 8-endo-trig cyclizations of these $(E)$-1-propenyl-substituted substrates is proposed in accordance to the previously postulated eightmembered pseudo-chair-like transition structures (Figure 4). The methoxycarbonyl group and substituent $\mathrm{R}$ at the ketyl moiety are both occupying preferred pseudo-equatorial positions. In our drawing, the olefin approaches the samarium ketyl from the backside perpendicularly to the bulky samariumoxy group. The methyl substituent at the alkene moiety prefers a staggered position in between the bulky samariumoxy group and substituent $\mathrm{R}$.
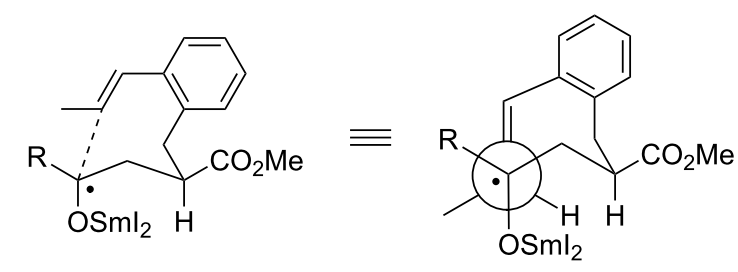

Figure 4: Proposed transition structure for the cyclization of $(E)$-1propenyl-substituted substrates (HMPA ligands and proton donors $\mathrm{ROH}$ at the samarium are omitted for simplicity).

Another indication of the considerable steric repulsion introduced by the methyl substituent at the $\beta$-styryl position is provided by the cyclizations of sterically more constrained cyclohexanone derivatives 26a and 26b (Scheme 10). In these two cases both the usually preferred unlike-configured precursor 26a and the disfavoured like-configured $26 \mathbf{b}$ gave only low quantities of cyclooctanol products, 27 and 29, respectively, along with the recovered starting material and either the ketyl-aryl coupling product $\mathbf{2 8}$ or the fragmentation product 23 (Scheme 10).

The stereochemical assignments for products $\mathbf{2 7}$ and $\mathbf{2 9}$ are based on the relative configuration of their precursors. The existence or lack of lactone formation allows for assigning the configuration of the bridgehead carbon bearing the hydroxyl group. The assignment of the centre with the methyl group is based on a strong NOESY-correlation between the methyl protons and the bridgehead proton. It is noteworthy that the stereoselectivity of the cyclization for cyclic ketones is clearly controlled by the relative configuration of the precursors and that the hydroxyl group is generated trans to the vicinal substituents. The reactivity of the sterically more demanding $\beta$-styryl-substituted substrates was strongly retarded due to rigidity and bulkiness of the integrated cyclohexane ring, which in the previous cyclization examples afforded cyclooctanol products with good yield and excellent stereoselectivity.

The cyclopentanone-derived analogues of $\mathbf{2 6 a} / \mathbf{b}$ were also examined in this samarium diiodide-promoted transformation, but among the isolated products only the starting materials could be unequivocally identified. Not surprisingly, the $(E)-1$ propenyl analogue of the bulky diisopropyl ketone-derived substrate 14 only afforded the corresponding fragmentation product. In this case again small amounts of the $n$-propyl ester were detected (compare Scheme 7).

The influence of the configuration of the reacting alkene was also studied. The cyclization of (Z)-1-propenyl-substituted 30, which is isomeric to already examined $(E)$-1-propenyl-ketoester 24, afforded the corresponding cyclooctanol 31 with considerably lower efficacy (Scheme 11, compare Scheme 9). The<smiles>C/C=C/c1ccccc1C[C@H](C(C)=O)[C@H]1CCCCC1=O</smiles>

26a<smiles>C/C=C/c1ccccc1C[C@H](C(C)=O)[C@H]1CCCCC1=O</smiles>

26b

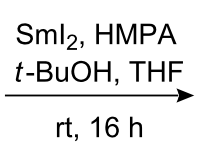

rt, $16 \mathrm{~h}$ $\underset{t-\mathrm{BuOH}, \mathrm{THF}}{\longrightarrow}$

$\mathrm{rt}, 16 \mathrm{~h}$<smiles>CCCCC[C@@]1(O)C(C(=O)OC)Cc2ccccc2C[C@H]1C</smiles>

$2711 \%$

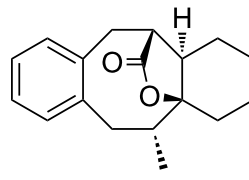

$299 \%$

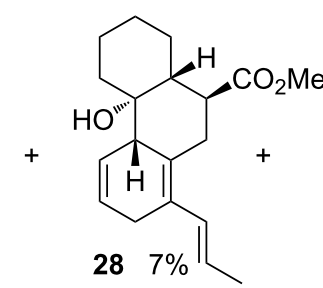

s.m.

$42 \%$

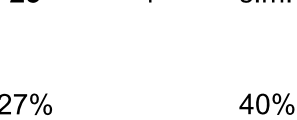

Scheme 10: Attempted samarium diiodide-induced cyclizations with (E)-1-propenyl-substituted precursors 26a and 26b 
<smiles>C/C=C\c1ccccc1CC(CC(=O)C(C)C)CC(C)C</smiles>

30

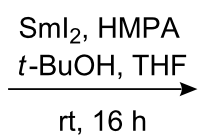

$\mathrm{rt}, 16 \mathrm{~h}$

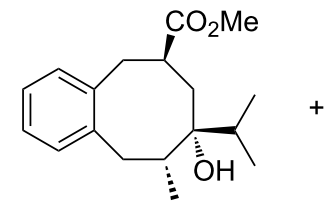

$318 \%$<smiles>C/C=C\c1ccccc1CCC(C)=O</smiles>

$3231 \%$
$32 \%$

Scheme 11: Attempted samarium diiodide-induced cyclization of (Z)-1-propenyl-substituted precursor 30.

reaction mixture afforded considerable amounts of fragmentation product $\mathbf{3 2}$ along with unchanged starting material.

The configuration of product $\mathbf{3 1}$ is based on the comparison with the isomeric product $\mathbf{2 5}$. Analysis of a possible transition structure analogous to that proposed for the cyclization of $(E)$ 1-propenyl-substituted $\gamma$-ketoesters (compare Figure 4) reveals that the $Z$-configured alkene has to arrange the methyl substituent in a highly unfavourable endo-cyclic position of the newly formed ring. This apparently causes high steric repulsion and thus strongly suppressed reactivity.

In order to further define the scope and limitations of the samarium diiodide-induced reaction we then studied the cyclization of $\beta$-styryl-substituted $\gamma$-ketoester 33 . This precursor has the preferred $(E)$-configured alkene substructure, but is equipped with branched substituents at the ketone and alkene moieties (Scheme 12). The starting material was completely consumed in this reaction, affording a moderate yield of the eight-membered carbocycle $\mathbf{3 4}$ together with a fairly high amount of fragmentation product $\mathbf{3 5}$. The obtained product ratio suggests that in this example, the cyclization is roughly two times slower than the fragmentation. When a phenyl group was introduced to the $\beta$-styrene position the cyclization of $\gamma$-ketoester 36 mainly afforded the desired cyclooctanol derivative 37, along with several undefined side products in low quantities and $20 \%$ of unconsumed starting material (Scheme 12). It has to be emphasized here, that the 1,2-diarylalkene unit can potentially react with the samarium ketyl at both carbon atoms affording two different stabilized benzylic radicals. Therefore it is an interesting observation that the 8-endo-trig cyclization mode is preferred over the possible 7-exo-trig mode for the reaction of compound $\mathbf{3 6}$.

The configurations of products $\mathbf{3 4}$ and $\mathbf{3 7}$ are assigned with the aid of NOESY-correlations and by comparison with the NMRspectroscopic data of analogous compounds obtained after cyclizations of $(E)$-1-propenyl-substituted $\gamma$-ketoesters.

In contrary to the reaction of acyclic ketone 36, stilbenyl-substituted cyclohexanone derivatives $\mathbf{3 8 \mathbf { a }}$ and $\mathbf{3 8 \mathbf { b }}$ both preferred to undergo a 7-exo-trig cyclization, yielding tricyclic cycloheptanol derivative 39 and tetracyclic lactone 40, respectively (Scheme 13). Similarly as in cyclizations of the cyclohexanone-<smiles>COC(=O)C(Cc1ccccc1/C=C/c1ccccc1)C1CCCCC1=O</smiles>

$\mathrm{Sml}_{2}, \mathrm{HMPA}$ $t$-BuOH, THF $\mathrm{rt}, 16 \mathrm{~h}$ $38 \mathrm{a}$<smiles>CC(=O)C1Cc2ccccc2C(Cc2ccccc2)C2(O)CCCCC12</smiles>

$3944 \%$<smiles>CC(=O)[C@H](Cc1ccccc1/C=C/c1ccccc1)[C@H]1CCCCC1=O</smiles>

$38 b$

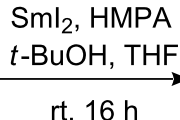

$\mathrm{rt}, 16 \mathrm{~h}$

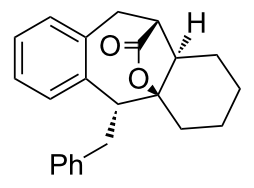

$4063 \%$
Scheme 13: Samarium diiodide-induced cyclizations of diastereomeric stilbenyl-substituted $\mathrm{y}$-ketoesters $\mathbf{3 8 a}$ and $\mathbf{3 8 b}$.<smiles></smiles>

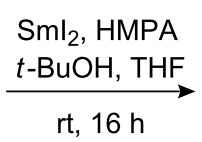

$\mathrm{rt}, 16 \mathrm{~h}$<smiles>[R]C1Cc2ccccc2CC(C(C)=O)CC1(O)C(C)C</smiles>

$3424 \%$

$3747 \%$<smiles>[R]C=Cc1ccccc1CCC(C)=O</smiles>

$3547 \%$

$20 \%$ 
derived ketoesters with terminally substituted alkenes $\mathbf{2 6} \mathbf{a} / \mathbf{b}$, the 8-endo-trig cyclization pathway may be quite hampered in the cases of $\mathbf{3 8} \mathbf{a}$ and $\mathbf{3 8 \mathbf { b }}$. However, due to the radical stabilizing properties of the terminal phenyl substituent, the 7-exo-trig pathway is now possible. It is probable that the restricted conformational flexibility of the cyclic ketones leads to higher steric and torsional strain in an alternative eight-membered transition structure. This assumption is supported by the observation that conformationally more flexible acyclic $\gamma$-ketoesters, such as 36, prefer the 8-endo-trig cyclization mode. Further-

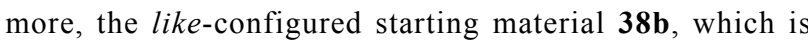
disfavoured in 8-endo-trig cyclizations, afforded the cycloheptanol derivative with even better efficacy than the unlike-configured 38a.

The constitution and the relative configuration of compound $\mathbf{4 0}$, featuring a tetracyclic lactone-bridged core, were unambiguously determined by an X-ray crystal structure (Figure 5) [59]. The constitution of compound $\mathbf{3 9}$ was assigned as a cycloheptanol derivative based on the similarities of its ${ }^{13} \mathrm{C}$ NMR data with those of $\mathbf{4 0}$ rather than those of the analogous eightmembered carbocycles. The configuration of $\mathbf{3 9}$ was assigned by using the following arguments: the relative configuration of

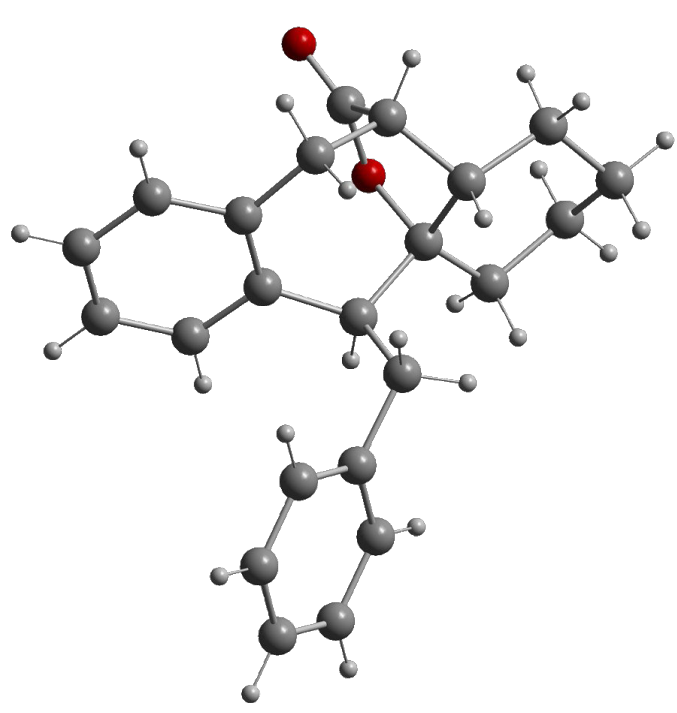

Figure 5: Molecular structure (Diamond [52]) of compound $\mathbf{4 0}$ the unlike-configured precursor should be transferred to the product and the bridgehead hydroxyl group should be in trans-relationship to the methoxycarbonyl group since no lactone formation was observed. The configuration of the stereogenic centre with the phenyl group of $\mathbf{3 9}$ is based on NOESY-correlations between the exocyclic benzylic protons and the bridgehead proton.

An attempt to cyclize $\gamma$-ketoester 41 featuring a $\beta$-dialkylsubstituted styryl moiety furnished only minor amounts of the ketyl-aryl coupling products $\mathbf{4 2}$ and $\mathbf{4 3}$ (Scheme 14). Similar to some other reactions leading mainly to side products, trace amounts of $n$-propyl ester of $\mathbf{4 2}$ of unknown origin were detected. Although the precursor was completely consumed, the missing material could not be identified. The relative configuration of the hexahydronaphthalene derivatives was assigned by the comparison of spectroscopic data with that of the previously described analogous compounds [57].

\section{Conclusion}

Samarium diiodide-mediated 8-endo-trig cyclizations of styrylsubstituted $\gamma$-ketoesters bearing alkyl or aryl substituents at the $\alpha$ - or $\beta$-styryl carbon were systematically studied. The stereoselectivity of these transformations was strongly influenced by the steric bulk at the ketone and alkene moieties. Acyclic $\gamma$-ketoesters such as A cyclized very efficiently, affording mixtures of $c i s$ - and trans-products $\mathbf{B}$ and $\mathbf{C}$ with improving cis/ trans stereoselectivity by increase of the size of the ketone substituents (Scheme 15).

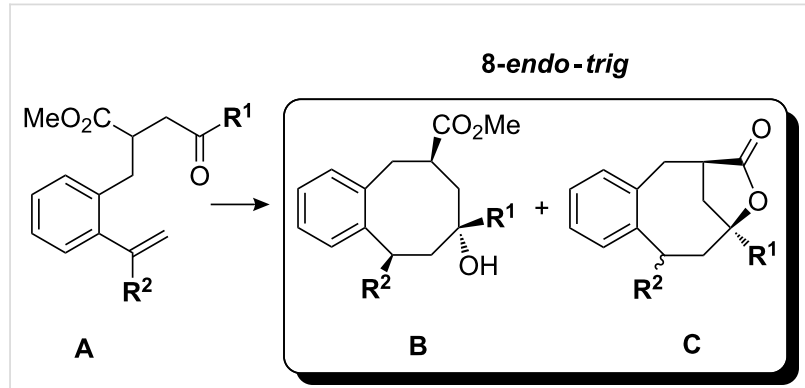

Scheme 15: Typical products of samarium diiodide-induced 8-endotrig cyclizations of $\alpha$-styryl-substituted $\mathrm{\gamma}$-ketoesters.<smiles>CC(=O)CC(Cc1ccccc1C=C(C)C)C(C)=O</smiles>

41

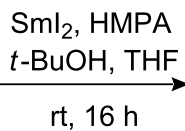

rt, $16 \mathrm{~h}$

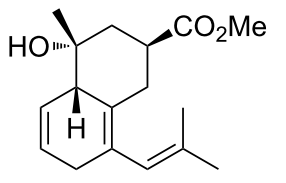

$4214 \%$

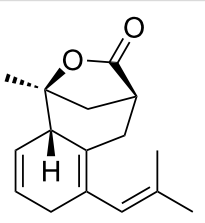

$437 \%$

Scheme 14: Attempted cyclization of $\beta$-dialkyl-substituted styrene derivative 41 . 
$\gamma$-Ketoesters with substituents at the $\beta$-styryl carbon such as $\mathbf{D}$ cyclized with similar efficiency, affording in most cases the 8-endo-trig-cyclization products E. Only cyclohexanone derived $\gamma$-ketoesters $\mathbf{F}$ preferred the 7-exo-trig over the 8-endotrig-cyclization mode (Scheme 16).

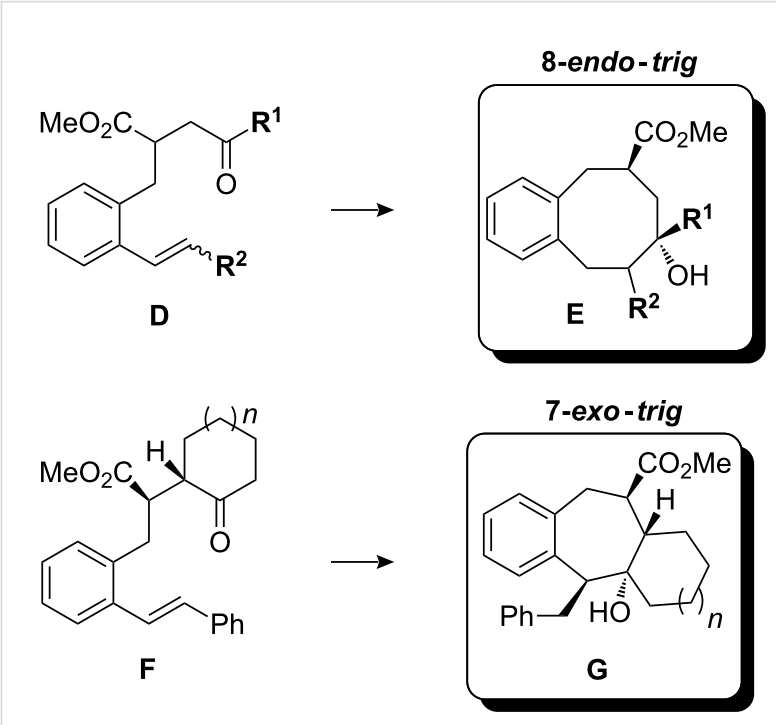

Scheme 16: Typical products of samarium diiodide-induced 8-endotrig cyclizations of $\beta$-styryl-substituted $\gamma$-ketoesters $\mathbf{D}$ and of 7 -exo-trig cyclizations of $\beta$-styryl-substituted $\gamma$-ketoesters $\mathbf{F}$.

A typical side reaction, which was observed for methyl ketones or cyclohexanone derivatives, was the ketyl-aryl coupling reaction leading to hexahydronaphthalene derivatives in low yields.

In conclusion, the intramolecular 8-endo-trig samarium ketylalkene coupling reaction is a flexible tool for the construction of highly substituted cyclooctanol derivatives. A careful design of the precursors following the rules determined in this study allows the synthesis of functionalized benzannulated cyclooctanol derivatives with a high degree of regio- and stereocontrol.

\section{Experimental}

General: All reactions were carried out under argon in flamedried flasks, and the components were added by syringe. All solvents were dried by standard methods. Thin layer chromatography (TLC) was carried out on commercial Polygram Sil G/ $\mathrm{UV}_{254}$ or Polygram Alox N/UV 254 (Macherey \& Nagel). Column chromatography was performed with 70-230 mesh silica gel (Merck) or neutral aluminium oxide (activity grade III; Fluka or Merck). Unless stated otherwise, ${ }^{1} \mathrm{H}$ NMR and ${ }^{13} \mathrm{C}$ NMR spectra were determined with Bruker AC 200, AC 300, DRX 500, Avance III 700 or Jeol Eclipse 500 instruments in $\mathrm{CDCl}_{3}$ solution. The chemical shifts refer to TMS or to the
$\mathrm{CDCl}_{3}$ signal $\left(\delta_{\mathrm{H}}=7.26 \mathrm{ppm} . \delta_{\mathrm{C}}=77.16 \mathrm{ppm}\right)$. IR spectra were measured with a Nicolet 205 5SXC FTIR-interferometer, equipped with a DTGS-detector. Melting points are uncorrected and determined with a melting point microscope Büchi 510. MS and HRMS analyses were performed with Finnigan MAT 711 $(\mathrm{EI}=80 \mathrm{eV}, 8 \mathrm{kV})$, MAT $95(\mathrm{EI}=70 \mathrm{eV})$, MAT CH7A $(\mathrm{EI}=$ $80 \mathrm{eV}, 3 \mathrm{kV})$ and CH5DF (FAB $=80 \mathrm{eV}, 3 \mathrm{kV})$ instruments. Elemental analyses were performed with Perkin-Elmer and Vario EL Elementar analytical equipment.

Preparation of all cyclization precursors analogously to known procedures is described in Supporting Information File 1.

\section{$\mathrm{Sml}_{2}$-induced cyclization}

General procedure A [60,61]: Samarium metal (2.4 equiv) and 1,2-diiodoethane ( 2.2 equiv) were placed under a flow of argon in a flame-dried, two-necked round-bottomed flask containing a magnetic stirring bar and a septum inlet. THF $(12 \mathrm{~mL} / \mathrm{mmol}$ of 1,2-diiodoethane) was added and the mixture was vigorously stirred at $\mathrm{rt}$ for $2 \mathrm{~h}$. HMPA (18 equiv) was added to this solution of $\mathrm{SmI}_{2}$ (2.2 equiv), and after $10 \mathrm{~min}$ of stirring, a solution of the substrate ( 1 equiv) and $t$ - BuOH ( 2 equiv) in THF (40 $\mathrm{mL} / \mathrm{mmol}$ of substrate) was added over $2 \mathrm{~h}$. The mixture was stirred at $\mathrm{rt}$ for $16 \mathrm{~h}$ and quenched with satd. aqueous $\mathrm{NaHCO}_{3}$ solution $(20 \mathrm{~mL} / \mathrm{mmol}$ of substrate). The phases were separated, and the aqueous layer was extracted with diethyl ether $(3 \times 15 \mathrm{~mL} / \mathrm{mmol}$ of substrate $)$. The combined organic layers were washed with water and brine $(10 \mathrm{~mL} / \mathrm{mmol}$ of substrate) and dried $\left(\mathrm{Na}_{2} \mathrm{SO}_{4}\right)$.

General procedure B [62,63]: Samarium metal (2.48 g, $16.5 \mathrm{mmol})$ and iodine $(3.81 \mathrm{~g}, 15.0 \mathrm{mmol})$ were placed under a flow of argon in a flame-dried, $250 \mathrm{~mL}$ round-bottomed flask containing a magnetic stirring bar. Then $150 \mathrm{~mL}$ of dry and oxygen-free THF was added and the mixture was covered from light, and stirred at $\mathrm{rt}$ for $24 \mathrm{~h}$ to give a $0.1 \mathrm{M}$ solution of $\mathrm{SmI}_{2}$ in THF. This solution was stored in the dark under argon at $\mathrm{rt}$ and aliquots were transferred with a syringe (2.2 equiv) into the two-necked reaction flask, and the solution was then used as described in General procedure A.

\section{$\mathrm{Sml}_{2}$-induced cyclization of $\mathbf{5 a}$}

General procedure B: 5a $(0.300 \mathrm{~g}, 1.00 \mathrm{mmol}), \mathrm{SmI}_{2}$ (2.20 mmol), HMPA (3.16 mL, $18.0 \mathrm{mmol})$ and $t$ - $\mathrm{BuOH}(0.148 \mathrm{~g}, 2.00 \mathrm{mmol})$. The crude product was purified by column chromatography (silica gel, ethyl acetate/hexane 1:9) to furnish $6(0.126 \mathrm{~g}, 42 \%)$ as colourless crystals $(\mathrm{mp}$ $\left.126-127^{\circ} \mathrm{C}\right)$ and $5 \mathrm{a}(0.069 \mathrm{~g}, 23 \%)$.

Methyl (6RS,6aSR,11aRS)-11a-hydroxy-6,6a,7,8,9,10,11,11a, 12,13-decahydro-5H-benzo $[a]$ cyclohepta $[e][8]$ annulene-6- 
carboxylate (6): ${ }^{1} \mathrm{H} \mathrm{NMR}\left(\mathrm{CDCl}_{3}, 700 \mathrm{MHz}\right): \delta=1.11-1.15$, $1.20-1.33,1.52-1.75,1.77-1.81$ (4 m, 2 H, 3 H, 6 H, 1 H, 6a-H, 7-H, 8-H, 9-H, 10-H, 11-H, OH), 1.88 (ddd, $J=2.2,8.0,14.4$ $\mathrm{Hz}, 1 \mathrm{H}, 12-\mathrm{H}), 2.06$ (ddd, $J=2.6,11.6,14.4 \mathrm{~Hz}, 1 \mathrm{H}, 12-\mathrm{H})$, 2.68 (ddd, $J=2.6,8.0,14.0 \mathrm{~Hz}, 1 \mathrm{H}, 13-\mathrm{H}), 2.85$ (dd, $J=4.6$, $14.2 \mathrm{~Hz}, 1 \mathrm{H}, 5-\mathrm{H}), 3.01$ (ddd, $J=4.6,5.2,10.6 \mathrm{~Hz}, 1 \mathrm{H}, 6-\mathrm{H})$, 3.18 (ddd, $J=2.2,11.6,14.0 \mathrm{~Hz}, 1 \mathrm{H}, 13-\mathrm{H}), 3.62$ (dd, $J=5.2$, $14.2 \mathrm{~Hz}, 1 \mathrm{H}, 5-\mathrm{H}), 3.69$ (s, $3 \mathrm{H}, \mathrm{CO}_{2} \mathrm{Me}$ ), 6.89-6.91, 7.12-7.18 $(2 \mathrm{~m}, 1 \mathrm{H}, 3 \mathrm{H}, \mathrm{Ar}) \mathrm{ppm} .{ }^{13} \mathrm{C} \mathrm{NMR}\left(\mathrm{CDCl}_{3}, 175 \mathrm{MHz}\right): \delta=$ 23.6, 29.1, 29.4, 29.5 (4 t, C-7, C-8, C-9, C-10), 31.5 (t, C-13), 34.9 (t, C-5), 45.0 (d, C-6a), 46.9, 47.0 (2 t, C-11, C-12), 51.4 (d, C-6), 126.1, 127.0, 129.1, 130.5, 136.8, 142.0 (4 d, 2 s, Ar), $51.2,176.1$ (q, s, $\mathrm{CO}_{2} \mathrm{Me}$ ) ppm. Signal for C-11a is not clearly visible. IR (KBr): $\tilde{v}=3500(\mathrm{O}-\mathrm{H}), 3060-2855(=\mathrm{C}-\mathrm{H}, \mathrm{C}-\mathrm{H})$, $1715(\mathrm{C}=\mathrm{O}) \mathrm{cm}^{-1} \cdot \mathrm{C}_{19} \mathrm{H}_{26} \mathrm{O}_{3}$ (302.4): calcd. C 75.46, H 8.67; found: $\mathrm{C} 75.36, \mathrm{H} 8.78$.

\section{$\mathrm{Sml}_{2}$-induced cyclization of $7 \mathbf{a}$}

General Procedure A: 7a $(0.296 \mathrm{~g}, 0.99 \mathrm{mmol}), \mathrm{SmI}_{2}$ $(2.20 \mathrm{mmol})$, HMPA $(3.16 \mathrm{~mL}, 18.0 \mathrm{mmol})$ and $t$-BuOH $(0.148 \mathrm{~g}, 2.00 \mathrm{mmol})$. The crude product was purified by column chromatography (silica gel, ethyl acetate/hexane 1:9) then HPLC (iso-propanol/hexane 7:93) to furnish $8(0.187 \mathrm{~g}$, $63 \%$ ) as colourless crystals ( $\mathrm{mp} 74-75^{\circ} \mathrm{C}$ ).

Methyl (4aSR,5RS,11RS,12aRS)-12a-hydroxy-11-methyl$1,2,3,4,4 a, 5,6,11,12,12 a-d e c a h y d r o-d i b e n z o[a, e][8]$ annulene5-carboxylate (8): ${ }^{1} \mathrm{H}$ NMR $\left(\mathrm{CDCl}_{3}, 500 \mathrm{MHz}\right): \delta=1.14-1.18$ (m, 2 H, 3-H, 4-H), 1.28 (d, J=7.0 Hz, 3 H, 11-Me), 1.30-1.34, 1.38-1.46, 1.54-1.58, 1.63-1.70 (4 m, 1 H, 3 H, 1 H, 2 H, 1-H, 2-H, 3-H, 4-H, 4a-H), 1.96 (dd, $J=4.9,15.2 \mathrm{~Hz}, 1 \mathrm{H}, 12-\mathrm{H})$, $2.08(\mathrm{dd}, J=11.5,15.2 \mathrm{~Hz}, 1 \mathrm{H}, 12-\mathrm{H}), 2.63$ (ddd, $J=4.7,5.8$, $10.6 \mathrm{~Hz}, 1 \mathrm{H}, 5-\mathrm{H}), 3.13-3.20$ (m, $2 \mathrm{H}, 6-\mathrm{H}), 3.35$ (dqd, $J=4.9$, 7.0, $11.5 \mathrm{~Hz}, 1 \mathrm{H}, 11-\mathrm{H}), 3.73$ (s, $\left.3 \mathrm{H}, \mathrm{CO}_{2} \mathrm{Me}\right), 6.98-7.00$, 7.12-7.21 (2 m, 1 H, $3 \mathrm{H}$, Ar) ppm, the signal for the $\mathrm{OH}$ group could not be assigned unambiguously. ${ }^{13} \mathrm{C} \mathrm{NMR}\left(\mathrm{CDCl}_{3}\right.$, $125 \mathrm{MHz}$ ): $\delta=21.3$ (t, C-2), 24.3 (q, 11-Me), 24.9 (t, C-3), 29.6 (t, C-4), 33.7 (d, C-11), 34.1 (t, C-6), 44.3 (t, C-1), 45.0 (d, C-4a), 53.2 (d, C-5), 54.0 (t, C-12), 73.2 (s, C-12a), 126.4, 127.4, 127.6, 131.0, 137.3, 144.8 (4 d, 2 s, Ar), 51.7, 176.6 (q, $\left.\mathrm{s}, \mathrm{CO}_{2} \mathrm{Me}\right) \mathrm{ppm}$. IR $(\mathrm{KBr}): \tilde{\mathrm{v}}=3510(\mathrm{br}, \mathrm{O}-\mathrm{H}), 3060-2860$ $(=\mathrm{C}-\mathrm{H}, \mathrm{C}-\mathrm{H}), 1725(\mathrm{C}=\mathrm{O}) \mathrm{cm}^{-1}$. MS (EI, $\left.70 \mathrm{eV}\right): \mathrm{m} / z(\%)=$ $302(21)[\mathrm{M}]^{+}, 284$ (100), 224 (64), 169 (57), 131 (53), 117 (60), 91 (44), 43 (46). $\mathrm{C}_{19} \mathrm{H}_{26} \mathrm{O}_{3}$ (302.4): calcd. C 75.46, H 8.67; found: C 75.23, H 8.71.

\section{$\mathrm{Sml}_{2}$-induced cyclization of $\mathbf{4}$}

General Procedure A: $4(0.200 \mathrm{~g}, 0.77 \mathrm{mmol}), \mathrm{SmI}_{2}$ $(1.70 \mathrm{mmol})$, HMPA $(2.43 \mathrm{~mL}, 13.8 \mathrm{mmol})$ and $t$-BuOH $(0.114 \mathrm{~g}, 1.54 \mathrm{mmol})$. The crude product was purified by column chromatography (silica gel, ethyl acetate/hexane 1:9) to furnish $9(0.080 \mathrm{~g}, 40 \%)$ as a colourless oil and $10(0.067 \mathrm{~g}$, $38 \%$ ) as colourless crystals (mp $130-132{ }^{\circ} \mathrm{C}$ ).

Methyl $(6 R S, 8 R S, 10 R S)-8-h y d r o x y-8,10-d i m e t h y l-$ $5,6,7,8,9,10-h e x a h y d r o-b e n z o-[8]$ annulene-6-carboxylate (9): Compound 9 shows temperature-dependent NMR spectra. At rt some signals appear broad; however, for measurements at $55{ }^{\circ} \mathrm{C}$, the signals are more clearly seen. ${ }^{1} \mathrm{H}$ NMR $\left(\mathrm{CDCl}_{3}\right.$, $\left.500 \mathrm{MHz}, 55^{\circ} \mathrm{C}\right): \delta=1.20(\mathrm{~s}, 3 \mathrm{H}, 8-\mathrm{Me}), 1.33(\mathrm{dd}, J=11.5$, $14.7 \mathrm{~Hz}, 1 \mathrm{H}, 7-\mathrm{H}), 1.33$ (d, $J=7.1 \mathrm{~Hz}, 3 \mathrm{H}, 10-\mathrm{Me}), 1.62$ (dd, $J=11.4,14.3 \mathrm{~Hz}, 1 \mathrm{H}, 9-\mathrm{H}), 1.67(\mathrm{dd}, J=3.8,14.7 \mathrm{~Hz}, 1 \mathrm{H}$, 7-H), 1.79-1.83 (m, $1 \mathrm{H}, 9-\mathrm{H}), 3.10$ (dddd, $J=2.9,3.8,7.5$, $11.5 \mathrm{~Hz}, 1 \mathrm{H}, 6-\mathrm{H}), 3.16$ (dd, $J=2.9,13.9 \mathrm{~Hz}, 1 \mathrm{H}, 5-\mathrm{H})$, $3.36-3.43(\mathrm{~m}, 1 \mathrm{H}, 10-\mathrm{H}), 3.43(\mathrm{dd}, J=7.5,13.9 \mathrm{~Hz}, 1 \mathrm{H}, 5-\mathrm{H})$, $3.68\left(\mathrm{~s}, 3 \mathrm{H}, \mathrm{CO}_{2} \mathrm{Me}\right), 6.97-6.99,7.06-7.10,7.17-7.25$ (3 m, 1 $\mathrm{H}, 1 \mathrm{H}, 2 \mathrm{H}$, Ar) ppm, the signal for the $\mathrm{OH}$ group could not be assigned unambiguously. ${ }^{13} \mathrm{C} \mathrm{NMR}\left(\mathrm{CDCl}_{3}, 125 \mathrm{MHz}, 55{ }^{\circ} \mathrm{C}\right)$ : $\delta=23.2(\mathrm{q}, 10-\mathrm{Me}), 30.2(\mathrm{~d}, \mathrm{C}-10), 32.3(\mathrm{t}, \mathrm{C}-5), 36.0(\mathrm{q}$, 8-Me), 36.5 (t, C-7), 42.2 (d, C-6), 55.1 (t, C-9), 71.5 (s, C-8), 125.1, 125.9, 127.1, 129.6, 136.5, 146.3 (4 d, $2 \mathrm{~s}, \mathrm{Ar}), 51.7$, 176.1 (q, s, $\mathrm{CO}_{2} \mathrm{Me}$ ) ppm. IR (neat): $\widetilde{v}=3500$ (br, O-H), 3100-2840 (=C-H, C-H), $1715(\mathrm{C}=\mathrm{O}) \mathrm{cm}^{-1}$. HRMS (ESI) calcd for $\mathrm{C}_{16} \mathrm{H}_{22} \mathrm{O}_{3}:[\mathrm{M}+\mathrm{H}]^{+}=217.1255,[\mathrm{M}+\mathrm{Na}]^{+}=239.1074$, $[\mathrm{M}+\mathrm{K}]^{+}=255.0813$; found: $217.1267,239.1095,255.0844$.

(2RS,5SR,7SR)-5,7-Dimethyl-1,5,6,7-tetrahydro-2,5methano-4-benzoxonin-3(2H)-one (10): ${ }^{1} \mathrm{H} \mathrm{NMR}\left(\mathrm{CDCl}_{3}\right.$, $500 \mathrm{MHz}): \delta=1.34(\mathrm{~d}, J=6.9 \mathrm{~Hz}, 3 \mathrm{H}, 7-\mathrm{Me}), 1.36(\mathrm{~s}, 3 \mathrm{H}$, 5-Me), 1.43 (dd, $J=1.1,13.9 \mathrm{~Hz}, 1 \mathrm{H}, 12-\mathrm{H}), 1.55$ (dd, $J=$ 11.3, 14.6 Hz, $1 \mathrm{H}, 6-\mathrm{H}), 1.74-1.79$ (m, $1 \mathrm{H}, 12-\mathrm{H}), 2.05-2.09$ (m, $1 \mathrm{H}, 6-\mathrm{H}), 2.76(\mathrm{dqd}, J=1.3,6.9,11.3 \mathrm{~Hz}, 1 \mathrm{H}, 7-\mathrm{H}), 3.15$ (dddd, $J=1.1,2.5,10.3,12.8 \mathrm{~Hz}, 1 \mathrm{H}, 2-\mathrm{H}), 3.20$ (dd, $J=12.8$, $14.5 \mathrm{~Hz}, 1 \mathrm{H}, 1-\mathrm{H}), 3.31(\mathrm{dd}, J=2.5,14.5 \mathrm{~Hz}, 1 \mathrm{H}, 1-\mathrm{H})$, 7.00-7.02, 7.15-7.18, 7.28-7.36 (3 m, $1 \mathrm{H}, 1 \mathrm{H}, 2 \mathrm{H}, \mathrm{Ar}) \mathrm{ppm}$. ${ }^{13} \mathrm{C} \mathrm{NMR}\left(\mathrm{CDCl}_{3}, 125 \mathrm{MHz}\right): \delta=22.5(\mathrm{q}, 7-\mathrm{Me}), 29.6(\mathrm{q}$, 5-Me), 30.0 (d, C-7), 34.2 (t, C-12), 34.5 (t, C-1), 39.3 (d, C-2), 51.4 (t, C-6), 86.3 (s, C-5), 125.4, 126.7, 127.9, 130.4, 136.8, 146.2 (4 d, $2 \mathrm{~s}, \mathrm{Ar}), 181.5$ (s, C-3) ppm. IR (KBr): $\tilde{\mathrm{v}}=$ 3065-2825 (=C-H, C-H), $1755(\mathrm{C}=\mathrm{O}) \mathrm{cm}^{-1} \cdot \mathrm{C}_{15} \mathrm{H}_{18} \mathrm{O}_{2}$ (230.3): calcd. C 78.23, H 7.88; found: C 78.49, H 7.93.

\section{$\mathrm{Sml}_{2}$-induced cyclization of $\mathbf{1 1}$}

General procedure A: Compound 11 (0.290 g, $1.01 \mathrm{mmol})$, $\mathrm{SmI}_{2}(2.22 \mathrm{mmol}), \mathrm{HMPA}(3.16 \mathrm{~mL}, 18.0 \mathrm{mmol})$ and $t$-BuOH $(0.150 \mathrm{~g}, 2.02 \mathrm{mmol})$. The crude product was purified by column chromatography (silica gel, ethyl acetate/hexane 1:9) to furnish $12(0.157 \mathrm{~g}, 54 \%)$ as a colourless oil and $13(0.072 \mathrm{~g}$, $28 \%$ ) as colourless crystals (mp $117-119^{\circ} \mathrm{C}$ ).

Methyl (6RS,8RS,10SR)-8-hydroxy-8-isopropyl-10-methyl$5,6,7,8,9,10$-hexahydro-benzo $[8]$ annulene-6-carboxylate 
(12): Compound 12 shows temperature-dependent NMR spectra. At rt most signals appear very broad; however, for measurements at $50{ }^{\circ} \mathrm{C}$, the signals are clearly seen. ${ }^{1} \mathrm{H} \mathrm{NMR}\left(\mathrm{CDCl}_{3}, 500 \mathrm{MHz}, 50{ }^{\circ} \mathrm{C}\right): \delta=0.85,0.86(2 \mathrm{~d}, J=6.9$ $\mathrm{Hz}, 2 \times 3 \mathrm{H}, \mathrm{CHMe} 2), 1.08(\mathrm{dd}, J=12.5,14.7 \mathrm{~Hz}, 1 \mathrm{H}, 7-\mathrm{H})$, 1.23 (br. s, $1 \mathrm{H}, \mathrm{OH}), 1.35$ (d, $J=7.0 \mathrm{~Hz}, 3 \mathrm{H}, 10-\mathrm{Me}$ ), 1.55 (sept, $J=6.9 \mathrm{~Hz}, 1 \mathrm{H}, \mathrm{CHMe}$ ), 1.62-1.69, 3.07-3.13 (2 m, 3 H, 2 H, 5-H, 6-H, 7-H, 9-H), 3.45 (dqd, $J=3.1,7.0,9.9 \mathrm{~Hz}, 1$ $\mathrm{H}, 10-\mathrm{H}), 3.54(\mathrm{dd}, J=7.6,14.0 \mathrm{~Hz}, 1 \mathrm{H}, 5-\mathrm{H}), 3.71(\mathrm{~s}, 3 \mathrm{H}$, $\left.\mathrm{CO}_{2} \mathrm{Me}\right), 6.99-7.01,7.09-7.12,7.21-7.30(3 \mathrm{~m}, 1 \mathrm{H}, 1 \mathrm{H}, 2 \mathrm{H}$, Ar) ppm. ${ }^{13} \mathrm{C} \mathrm{NMR}\left(\mathrm{CDCl}_{3}, 125 \mathrm{MHz}, 50{ }^{\circ} \mathrm{C}\right): \delta=16.7,17.2$ (2 q, CHMe $), 23.3$ (q, 10-Me), 29.1 (d, C-10), 31.9 (t, C-7), 32.7 (t, C-5), 42.2 (d, C-6), 43.2 (d, $\mathrm{CHMe}_{2}$ ), 50.3 (t, C-9), 74.8 (s, C-8), 124.7, 125.8, 127.1, 129.7, 136.6, 146.9 (4 d, 2 s, Ar), 51.6, 176.2 (q, s, $\mathrm{CO}_{2} \mathrm{Me}$ ) ppm. IR (neat): $\tilde{\mathrm{v}}=3515$ (br, O-H), 3100-2845 (=C-H, C-H), $1720(\mathrm{C}=\mathrm{O}) \mathrm{cm}^{-1}$. MS (EI, $\left.70 \mathrm{eV}\right)$ : $m / z(\%)=290(13)[\mathrm{M}]^{+}, 247(70), 215(85), 187(54), 145$ (73), 117 (40), 71 (26), 43 (100). $\mathrm{C}_{18} \mathrm{H}_{26} \mathrm{O}_{3}$ (290.4): calcd: $\mathrm{C}$ 74.45, H 9.02; found: C 74.71, H 8.83.

(2RS,5SR,7SR)-5-Isopropyl-7-methyl-1,5,6,7-tetrahydro-2,5methano-4-benzoxonin-3(2H)-one (13): ${ }^{1} \mathrm{H} \mathrm{NMR}\left(\mathrm{CDCl}_{3}\right.$, $500 \mathrm{MHz}): \delta=0.79,0.89\left(2 \mathrm{~d}, J=6.9 \mathrm{~Hz}, 2 \times 3 \mathrm{H}, \mathrm{CHMe} e_{2}\right.$, 1.27 (dd, $J=1.3,13.9 \mathrm{~Hz}, 1 \mathrm{H}, 12-\mathrm{H}), 1.35$ (d, $J=7.0 \mathrm{~Hz}, 3 \mathrm{H}$, 7-Me), 1.60 (dd, $J=11.1,14.4 \mathrm{~Hz}, 1 \mathrm{H}, 6-\mathrm{H}), 1.75$ (dd, $J=$ $10.8,13.9 \mathrm{~Hz}, 1 \mathrm{H}, 12-\mathrm{H}), 1.84$ (sept, $J=6.9 \mathrm{~Hz}, 1 \mathrm{H}, \mathrm{CHMe}$ ), $1.95(\mathrm{dd}, J=0.9,14.4 \mathrm{~Hz}, 1 \mathrm{H}, 6-\mathrm{H}), 2.70-2.77$ (m, $1 \mathrm{H}, 7-\mathrm{H})$, $3.10-3.15$ (m, 1 H, 2-H), 3.21 (dd, $J=12.8,14.8 \mathrm{~Hz}, 1 \mathrm{H}, 1-\mathrm{H})$, $3.32(\mathrm{dd}, J=2.9,14.8 \mathrm{~Hz}, 1 \mathrm{H}, 1-\mathrm{H}), 6.99-7.01,7.14-7.17$, 7.27-7.36 (3 m, $1 \mathrm{H}, 1 \mathrm{H}, 2 \mathrm{H}, \mathrm{Ar}) \mathrm{ppm} .{ }^{13} \mathrm{C} \mathrm{NMR}\left(\mathrm{CDCl}_{3}\right.$, $125 \mathrm{MHz}): \delta=16.6,17.4$ (2 q, CHMe $), 22.9$ (q, 7-Me), 29.6 (d, C-7), 30.5 (t, C-12), 34.6 (t, C-1), 38.5 (d, CHMe 2 ), 38.9 (d, C-2), 45.3 (t, C-6), 91.2 (s, C-5), 125.4, 126.6, 127.9, 130.3, 136.7, 146.6 (4 d, $2 \mathrm{~s}, \mathrm{Ar}), 181.7$ (s, C-3) ppm. IR (KBr): $\widetilde{v}=$ 3075-2850 (=C-H, C-H), $1765(\mathrm{C}=\mathrm{O}) \mathrm{cm}^{-1}$. MS $(\mathrm{EI}=70 \mathrm{eV})$ : $m / z(\%)=258(46)[\mathrm{M}]^{+}, 215(72), 187(41), 173(50), 145$ (69), 117 (37), 91 (28), 71 (32), 43 (100). $\mathrm{C}_{17} \mathrm{H}_{22} \mathrm{O}_{2}$ (258.4): calcd: C 79.03, H 8.58; found: C 79.09, H 8.41.

\section{$\mathrm{Sml}_{2}$-induced reaction of 14}

General procedure B: Compound 14 (0.276 g, $0.87 \mathrm{mmol})$, $\mathrm{SmI}_{2}(1.92 \mathrm{mmol})$, HMPA $(2.75 \mathrm{~mL}, 15.7 \mathrm{mmol})$ and $t$-BuOH $(0.129 \mathrm{~g}, 1.74 \mathrm{mmol})$. The crude product was purified by column chromatography (silica gel, ethyl acetate/hexane 1:9) to furnish $15(0.103 \mathrm{~g}, 58 \%)$ as a colourless oil.

Methyl 3-(2-isopropenylphenyl)propanoate (15): ${ }^{1} \mathrm{H} \mathrm{NMR}\left(\mathrm{CDCl}_{3}, 500 \mathrm{MHz}\right): \delta=2.07[\mathrm{br} \mathrm{s}, 3 \mathrm{H},=\mathrm{C}(\mathrm{Ar}) \mathrm{Me}]$, 2.60 (t, $J=8.2 \mathrm{~Hz}, 2 \mathrm{H}, 2-\mathrm{H}), 2.98$ (t, $J=8.2 \mathrm{~Hz}, 2 \mathrm{H}, 3-\mathrm{H})$, 3.69 (s, $3 \mathrm{H}, \mathrm{CO}_{2} \mathrm{Me}$ ), 4.87 (br. s, $1 \mathrm{H},=\mathrm{CH}_{2}$ ), 5.22 (br. s, $1 \mathrm{H}$, $\left.=\mathrm{CH}_{2}\right), 7.10-7.20(\mathrm{~m}, 4 \mathrm{H}, \mathrm{Ar}) \mathrm{ppm} .{ }^{13} \mathrm{C} \mathrm{NMR}\left(\mathrm{CDCl}_{3}, 100\right.$
$\mathrm{MHz}): \delta=25.3[\mathrm{q},=\mathrm{C}(\mathrm{Ar}) M e], 28.3(\mathrm{t}, \mathrm{C}-3), 35.9(\mathrm{t}, \mathrm{C}-2)$, $115.3\left(\mathrm{t},=\mathrm{CH}_{2}\right), 126.3,127.2,128.4,129.0,137.0,143.9,145.4$ $[4 \mathrm{~d}, 3 \mathrm{~s},=C(A r) \mathrm{Me}], 51.7,173.6\left(\mathrm{q}, \mathrm{s}, \mathrm{CO}_{2} \mathrm{Me}\right) \mathrm{ppm}$. IR (neat): $\tilde{v}=3065-2845(=\mathrm{C}-\mathrm{H}, \mathrm{C}-\mathrm{H}), 1735(\mathrm{C}=\mathrm{O}), 1640(\mathrm{C}=\mathrm{C}) \mathrm{cm}^{-1}$. MS $(\mathrm{EI}=70 \mathrm{eV}): m / z(\%)=204(23)[\mathrm{M}]^{+}, 130(47), 129(100)$, 115 (42), 91 (29), 28 (47). HRMS ( $80 \mathrm{eV})$ calcd for $\mathrm{C}_{13} \mathrm{H}_{16} \mathrm{O}_{2}$ : $[\mathrm{M}]^{+}=204.11504$; found: 204.11522 .

\section{$\mathrm{Sml}_{2}$-induced cyclization of 16}

General procedure A: Compound 16 (0.170 g, $0.49 \mathrm{mmol})$, $\mathrm{SmI}_{2}(1.08 \mathrm{mmol})$, HMPA $(1.54 \mathrm{~mL}, 8.77 \mathrm{mmol})$ and $t$-BuOH $(0.073 \mathrm{~g}, 0.98 \mathrm{mmol})$. The crude product was purified by column chromatography (silica gel, ethyl acetate/hexane 7:93 to 25:75) then HPLC (ethyl acetate/hexane 1:4) to furnish 17a $\left(0.058 \mathrm{~g}, 37 \%, \mathrm{mp} 162-165^{\circ} \mathrm{C}\right)$ and $\mathbf{1 7 b}(0.035 \mathrm{~g}, 22 \%, \mathrm{mp}$ $180-182{ }^{\circ} \mathrm{C}$ ) as colourless crystals.

(2RS,5SR,7RS)-5-Isopropyl-7-phenyl-1,5,6,7-tetrahydro-2,5methano-4-benzoxonin-3(2H)-one (17a): ${ }^{1} \mathrm{H} \mathrm{NMR}\left(\mathrm{CDCl}_{3}\right.$, $500 \mathrm{MHz}): \delta=0.89,0.98\left(2 \mathrm{~d}, J=6.9 \mathrm{~Hz}, 2 \times 3 \mathrm{H}, \mathrm{CHMe} e_{2}\right.$, 1.37 (dd, $J=1.3,14.0 \mathrm{~Hz}, 1 \mathrm{H}, 12-\mathrm{H}), 1.84$ (ddd, $J=1.3,11.0$, $14.0 \mathrm{~Hz}, 1 \mathrm{H}, 12-\mathrm{H}$ ), 1.93 (sept, $J=6.9 \mathrm{~Hz}, 1 \mathrm{H}, \mathrm{CHMe}$ ), 2.13 (dd, $J=11.6,14.0 \mathrm{~Hz}, 1 \mathrm{H}, 6-\mathrm{H}), 2.57$ (td, $J=1.3,14.0 \mathrm{~Hz}, 1$ H, 6-H), 3.21 (dddd, $J=1.3,3.3,11.0,13.0 \mathrm{~Hz}, 1 \mathrm{H}, 2-\mathrm{H}), 3.34$ $(\mathrm{dd}, J=13.0,15.3 \mathrm{~Hz}, 1 \mathrm{H}, 1-\mathrm{H}), 3.55(\mathrm{dd}, J=3.3,15.3 \mathrm{~Hz}, 1$ H, 1-H), 4.03 (dd, $J=1.3,11.6 \mathrm{~Hz}, 1 \mathrm{H}, 7-\mathrm{H}), 6.93-6.96$, 7.00-7.05, 7.08-7.13, 7.18-7.22, 7.27-7.32 (5 m, $1 \mathrm{H}, 1 \mathrm{H}, 2$ $\mathrm{H}, 3 \mathrm{H}, 2 \mathrm{H}, \mathrm{Ar}) \mathrm{ppm} .{ }^{13} \mathrm{C} \mathrm{NMR}\left(\mathrm{CDCl}_{3}, 125 \mathrm{MHz}\right): \delta=16.7$, 17.5 (2 q, CHMe $), 30.6$ (d, C-7), 34.9 (t, C-12), 39.0 (t, C-1), 39.1 (d, $\mathrm{CHMe}_{2}$ ), 40.7 (d, C-2), 41.5 (t, C-6), 90.8 (s, C-5), 126.5, 126.7, 128.0, 128.3, 128.5, 128.6, 130.3, 136.4, 145.2, 145.8 ( $7 \mathrm{~d}, 3 \mathrm{~s}, \mathrm{Ar}), 181.5$ (s, C-3) ppm. IR (KBr): $\widetilde{v}=$ 3085-2840 (=C-H, C-H), $1760(\mathrm{C}=\mathrm{O}) \mathrm{cm}^{-1}$. MS (EI, $\left.70 \mathrm{eV}\right)$ : $m / z(\%)=320(75)[\mathrm{M}]^{+}, 309$ (15), 277 (92), 179 (49), 91 (92), 43 (100). HRMS $(80 \mathrm{eV})$ calcd for $\mathrm{C}_{22} \mathrm{H}_{24} \mathrm{O}_{2}:[\mathrm{M}]^{+}=$ 320.17764 ; found: 320.17735 .

(2RS,5SR,7SR)-5-Isopropyl-7-phenyl-1,5,6,7-tetrahydro-2,5methano-4-benzoxonin-3(2H)-one (17b): ${ }^{1} \mathrm{H} \mathrm{NMR}\left(\mathrm{CDCl}_{3}\right.$, $500 \mathrm{MHz}): \delta=0.93,1.01(2 \mathrm{~d}, J=6.9 \mathrm{~Hz}, 2 \times 3 \mathrm{H}, \mathrm{CHMe})_{2}$, 1.86 (sept, $\left.J=6.9 \mathrm{~Hz}, 1 \mathrm{H}, \mathrm{C} H \mathrm{Me}_{2}\right), 2.34(\mathrm{dd}, J=2.5,14.5 \mathrm{~Hz}$, $1 \mathrm{H}, 6-\mathrm{H}), 2.38(\mathrm{dd}, J=9.5,13.8 \mathrm{~Hz}, 1 \mathrm{H}, 12-\mathrm{H}), 2.44(\mathrm{dd}, J=$ $12.4,14.5 \mathrm{~Hz}, 1 \mathrm{H}, 6-\mathrm{H}), 2.48$ (dd, $J=1.0,13.8 \mathrm{~Hz}, 1 \mathrm{H}, 12-\mathrm{H})$, 3.29 (dddd, $J=1.0,4.9,9.5,14.3 \mathrm{~Hz}, 1 \mathrm{H}, 2-\mathrm{H}), 3.30-3.36$ (m, $2 \mathrm{H}, 1-\mathrm{H}), 4.40(\mathrm{dd}, J=2.5,12.4 \mathrm{~Hz}, 1 \mathrm{H}, 7-\mathrm{H}), 6.79-6.82$, 7.04-7.07, 7.09-7.12, 7.23-7.29, 7.32-7.36 (5 m, $1 \mathrm{H}, 2 \mathrm{H}, 1$ $\mathrm{H}, 3 \mathrm{H}, 2 \mathrm{H}, \mathrm{Ar}) \mathrm{ppm} .{ }^{13} \mathrm{C} \mathrm{NMR}\left(\mathrm{CDCl}_{3}, 125 \mathrm{MHz}\right): \delta=16.8$, 17.3 (2 q, CHMe $), 37.0$ (t, C-12), 37.9 (t, C-1), 39.5 (t, C-6), 40.3 (d, $\mathrm{CHMe}_{2}$ ), 42.5 (d, C-2), 42.8 (d, C-7), 90.6 (s, C-5), 126.2, 126.6, 128.0, 128.3, 128.3, 128.6, 132.0, 135.6, 144.3, 145.3 (7 d, 3 s, Ar), 176.2 (s, C-3) ppm. IR (KBr): $\tilde{v}=$ 
3065-2875 (=C-H, C-H), $1755(\mathrm{C}=\mathrm{O}) \mathrm{cm}^{-1}$. MS (EI, $\left.70 \mathrm{eV}\right)$ : $m / z(\%)=320(100)[\mathrm{M}]^{+}, 277$ (97), 179 (45), 91 (91), 43 (59). $\mathrm{C}_{22} \mathrm{H}_{24} \mathrm{O}_{2}$ (320.4): calcd: C 82.46, H 7.55; found: $\mathrm{C} 81.83, \mathrm{H}$ 7.59 .

\section{$\mathrm{Sml}_{2}$-induced cyclization of 18}

General procedure A: Compound 18 (0.200 g, $0.77 \mathrm{mmol})$, $\mathrm{SmI}_{2}(1.70 \mathrm{mmol})$, HMPA $(2.43 \mathrm{~mL}, 13.8 \mathrm{mmol})$ and $t$-BuOH $(0.114 \mathrm{~g}, 1.54 \mathrm{mmol})$. The crude product was purified by column chromatography (silica gel, ethyl acetate/hexane 1:9) to furnish $19(0.108 \mathrm{~g}, 54 \%)$ and $20(0.040 \mathrm{~g}, 20 \%)$ as colourless oils.

Methyl (6RS,8SR,9SR)-8-hydroxy-8,9-dimethyl-5,6,7,8,9,10hexahydro-benzo[8]annulene-6-carboxylate (19): Compound 19 shows temperature-dependent NMR spectra. At rt several signals appear broad; however, for measurements at $55{ }^{\circ} \mathrm{C}$, signals are more clearly seen. ${ }^{1} \mathrm{H} \mathrm{NMR}\left(\mathrm{CDCl}_{3}, 500 \mathrm{MHz}, 55{ }^{\circ} \mathrm{C}\right): \delta=0.97(\mathrm{~d}, J=7.0 \mathrm{~Hz}, 3$ H, 9-Me), 1.17 (s, $3 \mathrm{H}, 8-\mathrm{Me}), 1.62$ (dd, $J=2.8,14.8 \mathrm{~Hz}, 1 \mathrm{H}$, 7-H), 1.77 (dd, $J=12.0,14.8 \mathrm{~Hz}, 1 \mathrm{H}, 7-\mathrm{H}), 1.94-2.01$ (m, $1 \mathrm{H}$, 9-H), 2.54 (dd, $J=9.1,14.0 \mathrm{~Hz}, 1 \mathrm{H}, 10-\mathrm{H}), 2.96-3.08$ (m, $3 \mathrm{H}$, 5-H, 6-H, 10-H), 3.22 (dd, $J=5.0,13.8 \mathrm{~Hz}, 1 \mathrm{H}, 5-\mathrm{H}$ ), 3.70 (s, $3 \mathrm{H}, \mathrm{CO}_{2} \mathrm{Me}$ ), 7.07-7.15 (m, $\left.4 \mathrm{H}, \mathrm{Ar}\right) \mathrm{ppm}$, the signal for the $\mathrm{OH}$ group could not be assigned unambiguously. ${ }^{13} \mathrm{C}$ NMR $\left(\mathrm{CDCl}_{3}, 125 \mathrm{MHz}, 55^{\circ} \mathrm{C}\right): \delta=17.0$ (q, 9-Me), 32.0 (q, 8-Me), 35.1 (t, C-5), 35.8 (t, C-7), 37.4 (t, C-10), 43.0 (d, C-6), 47.0 (d, C-9), 74.8 (s, C-8), 126.8, 127.0, 130.6, 130.7, 138.1, 139.7 (4 d, $2 \mathrm{~s}, \mathrm{Ar}$ ), 51.7, 176.3 (q, s, $\mathrm{CO}_{2} \mathrm{Me}$ ) ppm. IR (neat): $\widetilde{v}=3510$ (br, O-H), 3100-2850 (=C-H, C-H), $1720(\mathrm{C}=\mathrm{O}) \mathrm{cm}^{-1}$. $\mathrm{C}_{16} \mathrm{H}_{22} \mathrm{O}_{3}$ (262.3): calcd: C 73.25, H 8.45; found: C 73.43, H 8.30 .

Methyl (2SR,4RS,4aSR)-4-hydroxy-4-methyl-8-[(1E)propen-1-yl]-1,2,3,4,4a,7-hexahydro-naphthalene-2-carboxylate (20): ${ }^{1} \mathrm{H} \mathrm{NMR}\left(\mathrm{CDCl}_{3}, 500 \mathrm{MHz}\right): \delta=1.02(\mathrm{~s}, 3 \mathrm{H}$, 4-Me), 1.79 (dd, $J=1.5,6.6 \mathrm{~Hz}, 3 \mathrm{H},=\mathrm{CHMe}), 1.87-1.91$ (m, 2 H, 1-H, 3-H), 2.07 (dd, $J=3.8,12.5 \mathrm{~Hz}, 1 \mathrm{H}, 3-\mathrm{H}), 2.37$ (tt, $J=$ $3.8,12.9 \mathrm{~Hz}, 1 \mathrm{H}, 2-\mathrm{H}), 2.70-2.84$ (m, $3 \mathrm{H}, 1-\mathrm{H}, 7-\mathrm{H}), 3.21$ (dd, $J=1.6,3.8 \mathrm{~Hz}, 1 \mathrm{H}, 4 \mathrm{a}-\mathrm{H}), 3.72\left(\mathrm{~s}, 3 \mathrm{H}, \mathrm{CO}_{2} \mathrm{Me}\right), 5.64$ (qd, $J=$ $6.6,15.6 \mathrm{~Hz}, 1 \mathrm{H},=\mathrm{CHMe}), 5.84-5.87,5.89-5.92(2 \mathrm{~m}, 2 \times 1$ $\mathrm{H}, 5-\mathrm{H}, 6-\mathrm{H}$ ), 6.53 (qd, $J=1.5,15.6 \mathrm{~Hz}, 1 \mathrm{H}, \mathrm{CH}=\mathrm{CHMe}$ ) ppm, the signal for the $\mathrm{OH}$ group could not be assigned unambiguously. ${ }^{13} \mathrm{C} \mathrm{NMR}\left(\mathrm{CDCl}_{3}, 125 \mathrm{MHz}\right): \delta=18.9$ (q, $\left.=\mathrm{CHMe}\right)$, 22.0 (q, 4-Me), 27.5 (t, C-1), 31.2 (t, C-7), 41.0 (d, C-2), 44.0 (t, C-3), 50.2 (d, C-4a), 74.6 (s, C-4), 123.2, 124.8, 125.8, 126.6, $128.2,129.3\left(4 \mathrm{~d}, 2 \mathrm{~s},=\mathrm{CH},=\mathrm{C}_{\mathrm{q}}\right), 52.0,175.2\left(\mathrm{q}, \mathrm{s}, \mathrm{CO}_{2} \mathrm{Me}\right)$ $\mathrm{ppm}$. Due to instability of the sample and storage before the MS analysis was accomplished, only the rearomatized product could be detected. HRMS (ESI) calcd for $\mathrm{C}_{16} \mathrm{H}_{20} \mathrm{O}_{3}$ : $[\mathrm{M}+\mathrm{Na}]^{+}=$ 283.1305; found: 283.1295 .

\section{$\mathrm{Sml}_{2}$-induced cyclization of $\mathbf{2 1}$}

General procedure B: Compound 21 (0.270 g, $0.99 \mathrm{mmol})$, $\mathrm{SmI}_{2}(2.20 \mathrm{mmol})$, HMPA $(3.16 \mathrm{~mL}, 18.0 \mathrm{mmol})$ and $t$-BuOH $(0.148 \mathrm{~g}, 2.00 \mathrm{mmol})$. The crude product was purified by column chromatography (silica gel, ethyl acetate/hexane 1:9), then HPLC (iso-propanol/hexane 2:98) to furnish 22 (0.152 g, 56\%) and $23(0.012 \mathrm{~g}, 6 \%)$ as colourless oils.

Methyl (6RS,8SR,9SR)-8-ethyl-8-hydroxy-9-methyl$5,6,7,8,9,10$-hexahydro-benzo[ 8$]$ annulene-6-carboxylate (22): Compound 22 shows temperature-dependent NMR spectra. At rt several signals appear broad; however, for measurements at $40{ }^{\circ} \mathrm{C}$, the signals are more clearly seen. ${ }^{1} \mathrm{H} \mathrm{NMR}\left(\mathrm{CDCl}_{3}, 500 \mathrm{MHz}, 40{ }^{\circ} \mathrm{C}\right): \delta=0.87(\mathrm{t}, J=7.2 \mathrm{~Hz}, 3$ $\mathrm{H}, 8-\mathrm{CH}_{2} \mathrm{Me}$ ), 0.92 (d, $\left.J=6.9 \mathrm{~Hz}, 3 \mathrm{H}, 9-\mathrm{Me}\right), 1.39,1.50$ (2 qd, $\left.J=7.2,14.4 \mathrm{~Hz}, 2 \times 1 \mathrm{H}, 8-\mathrm{CH}_{2} \mathrm{Me}\right), 1.56-1.70(\mathrm{~m}, 2 \mathrm{H}, 7-\mathrm{H})$, 1.97-2.03 (m, $1 \mathrm{H}, 9-\mathrm{H}), 2.55$ (dd, $J=8.5,13.6 \mathrm{~Hz}, 1 \mathrm{H}, 10-\mathrm{H})$, 2.97-3.02 (m, $1 \mathrm{H}, 6-\mathrm{H}), 3.05-3.13$ (m, $2 \mathrm{H}, 5-\mathrm{H}, 10-\mathrm{H}), 3.27$ $(\mathrm{dd}, J=4.0,13.7 \mathrm{~Hz}, 1 \mathrm{H}, 5-\mathrm{H}), 3.72\left(\mathrm{~s}, 3 \mathrm{H}, \mathrm{CO}_{2} \mathrm{Me}\right)$, 7.08-7.11, 7.14-7.18 (2 m, $1 \mathrm{H}, 3 \mathrm{H}, \mathrm{Ar}) \mathrm{ppm}$, the $\mathrm{OH}$ group could not be assigned unambiguously. ${ }^{13} \mathrm{C} \mathrm{NMR}\left(\mathrm{CDCl}_{3}\right.$, $\left.125 \mathrm{MHz}, 40{ }^{\circ} \mathrm{C}\right): \delta=7.1\left(\mathrm{q}, 8-\mathrm{CH}_{2} \mathrm{Me}\right), 16.0(\mathrm{q}, 9-\mathrm{Me}), 33.4(\mathrm{t}$, C-7), 35.3 (t, C-5), 36.6 (t, 8- $\mathrm{CH}_{2} \mathrm{Me}$ ), 36.8 (t, C-10), 43.0 (d, C-6), 44.2 (d, C-9), 75.7 (s, C-8), 126.7, 126.9, 130.6, 130.7, 138.3, 139.7 (4 d, $2 \mathrm{~s}, \mathrm{Ar}$ ), 51.6, 176.4 (q, s, $\mathrm{CO}_{2} \mathrm{Me}$ ) ppm. IR (neat): $\tilde{v}=3535$ (br, O-H), 3060-2860 (=C-H, C-H), 1720 $(\mathrm{C}=\mathrm{O}) \mathrm{cm}^{-1}$. HRMS (ESI) calcd for $\mathrm{C}_{17} \mathrm{H}_{24} \mathrm{O}_{3}:[\mathrm{M}+\mathrm{Na}]^{+}=$ 299.1618; found: 299.1614 .

Methyl 3-\{2-[(1E)-propen-1-yl]phenyl\}propanoate (23): ${ }^{1} \mathrm{H} \mathrm{NMR}\left(\mathrm{CDCl}_{3}, 400 \mathrm{MHz}\right): \delta=1.90(\mathrm{dd}, J=1.6,6.6$ $\mathrm{Hz}, 3 \mathrm{H},=\mathrm{CHMe}$ ), 2.57 (t, $J=8.2 \mathrm{~Hz}, 2 \mathrm{H}, 2-\mathrm{H}), 2.99$ (t, $J=$ $8.2 \mathrm{~Hz}, 2 \mathrm{H}, 3-\mathrm{H}), 3.69$ (s, $3 \mathrm{H}, \mathrm{CO}_{2} \mathrm{Me}$ ), 6.12 (qd, $J=6.6,15.5$ $\mathrm{Hz}, 1 \mathrm{H},=\mathrm{C} H \mathrm{Me}), 6.62(\mathrm{qd}, J=1.6,15.5 \mathrm{~Hz}, 1 \mathrm{H},=\mathrm{C} H \mathrm{Ar})$, 7.10-7.21, 7.39-7.42 (2 m, $3 \mathrm{H}, 1 \mathrm{H}, \mathrm{Ar}) \mathrm{ppm} .{ }^{13} \mathrm{C} \mathrm{NMR}$ $\left(\mathrm{CDCl}_{3}, 100 \mathrm{MHz}\right): \delta=19.0(\mathrm{q},=\mathrm{CHMe}), 28.6(\mathrm{t}, \mathrm{C}-3), 35.2(\mathrm{t}$, C-2), 126.2, 126.8, 127.2, 128.1, 128.2, 129.3, 136.9, 137.2 (6 $\mathrm{d}, 2 \mathrm{~s}, \mathrm{ArCH}=\mathrm{CH}), 51.8,173.6$ (q, s, $\mathrm{CO}_{2} \mathrm{Me}$ ) ppm. IR (neat): $\tilde{\mathrm{v}}$ $=3065-2850(=\mathrm{C}-\mathrm{H}, \mathrm{C}-\mathrm{H}), 1735(\mathrm{C}=\mathrm{O}), 1600(\mathrm{C}=\mathrm{C}) \mathrm{cm}^{-1}$. HRMS (ESI) calcd for $\mathrm{C}_{13} \mathrm{H}_{16} \mathrm{O}_{2}:[\mathrm{M}+\mathrm{Na}]^{+}=227.1043$, $[\mathrm{M}+\mathrm{K}]^{+}=243.0782$; found: $227.1018,243.0936$.

\section{$\mathrm{Sml}_{2}$-induced cyclization of $\mathbf{2 4}$}

General procedure A: Compound 24 (0.300 g, $1.04 \mathrm{mmol})$, $\mathrm{SmI}_{2}(2.30 \mathrm{mmol})$, HMPA $(3.30 \mathrm{~mL}, 18.8 \mathrm{mmol})$ and $t$-BuOH $(0.156 \mathrm{~g}, 2.10 \mathrm{mmol})$. The crude product was purified by column chromatography (silica gel, ethyl acetate/hexane 1:9) to furnish $25(0.188 \mathrm{~g}, 63 \%)$ as colourless crystals (mp 89-90 $\left.{ }^{\circ} \mathrm{C}\right)$.

Methyl (6RS,8RS,9SR)-8-hydroxy-8-isopropyl-9-methyl$5,6,7,8,9,10$-hexahydro-benzo $[8]$ annulene-6-carboxylate 
(25): Compound 25 shows temperature-dependent spectra. At rt most signals appear very broad; however, for measurements at $65{ }^{\circ} \mathrm{C}$, the signals are clearly seen; ${ }^{1} \mathrm{H}$ NMR $\left(d_{6}\right.$-DMSO, $\left.500 \mathrm{MHz}, 65^{\circ} \mathrm{C}\right): \delta=0.78(\mathrm{~d}, J=7.0 \mathrm{~Hz}, 3 \mathrm{H}, 9-\mathrm{Me}), 0.85$, $0.86(2 \mathrm{~d}, J=6.7 \mathrm{~Hz}, 2 \times 3 \mathrm{H}, \mathrm{CHMe}), 1.14(\mathrm{dd}, J=12.7,14.9$ $\mathrm{Hz}, 1 \mathrm{H}, 7-\mathrm{H}), 1.40$ (dd, $J=2.7,14.9 \mathrm{~Hz}, 1 \mathrm{H}, 7-\mathrm{H}), 1.49$ (sept, $\left.J=6.7 \mathrm{~Hz}, 1 \mathrm{H}, \mathrm{C} H \mathrm{Me}_{2}\right), 2.01-2.07$ (m, $\left.1 \mathrm{H}, 9-\mathrm{H}\right), 2.33$ (dd, $J$ $=5.9,13.8 \mathrm{~Hz}, 1 \mathrm{H}, 10-\mathrm{H}), 2.92(\mathrm{dd}, J=2.4,13.4 \mathrm{~Hz}, 1 \mathrm{H}$, 5-H), 2.99 (dddd, $J=2.4,2.7,6.6,12.7 \mathrm{~Hz}, 1 \mathrm{H}, 6-\mathrm{H}), 3.33$ (dd, $J=2.0,13.8 \mathrm{~Hz}, 1 \mathrm{H}, 10-\mathrm{H}), 3.44(\mathrm{dd}, J=6.6,13.4 \mathrm{~Hz}, 1 \mathrm{H}$, 5-H), 3.61 (s, $\left.3 \mathrm{H}, \mathrm{CO}_{2} \mathrm{Me}\right), 6.89-6.91,7.06-7.12$ (2 m, $1 \mathrm{H}, 3$ $\mathrm{H}$, Ar) ppm, the signal for the $\mathrm{OH}$ group could not be assigned unambiguously. ${ }^{13} \mathrm{C}$ NMR $\left(d_{6}\right.$-DMSO, $\left.125 \mathrm{MHz}, 65{ }^{\circ} \mathrm{C}\right): \delta=$ 13.3 (q, 9-Me), 15.7, 16.2 (2 q, CHMe $), 28.0$ (t, C-7), 33.2 (t, C-5), 34.9 (t, C-10), 36.0 (d, $\mathrm{CHMe}_{2}$ ), 39.9 (d, C-9), 40.9 (d, C-6), 74.8 (s, C-8), 125.2, 125.7, 129.5, 130.8, 137.4, 139.3 (4 d, 2 s, Ar), 50.8, 175.1 (q, s, $\mathrm{CO}_{2} \mathrm{Me}$ ) ppm. IR (KBr): $\widetilde{v}=3490$ (br, O-H), 3000-2840 (=C-H, C-H), $1715(\mathrm{C}=\mathrm{O}) \mathrm{cm}^{-1}$. MS (EI $=70 \mathrm{eV}): m / z(\%)=290(24)[\mathrm{M}]^{+}, 247(74), 215(90), 187$ (100), 157 (54), 117 (54), 71 (21), 43 (80). $\mathrm{C}_{18} \mathrm{H}_{26} \mathrm{O}_{3}$ (290.4): calcd: C 74.45, H 9.02; found: C 74.51, H 8.74.

\section{$\mathrm{Sml}_{2}$-induced cyclization of 26a}

General procedure A: Compound 26a $(0.300 \mathrm{~g}, 1.00 \mathrm{mmol})$, $\mathrm{SmI}_{2}(2.20 \mathrm{mmol})$, HMPA $(3.16 \mathrm{~mL}, 18.0 \mathrm{mmol})$ and $t$-BuOH $(0.148 \mathrm{~g}, 2.00 \mathrm{mmol})$. The crude product was purified by column chromatography (silica gel, ethyl acetate/hexane 1:9), then HPLC (ethyl acetate/hexane 15:85) to furnish 27 and $28(0.054 \mathrm{~g}, 18 \%)$ as an inseparable mixture $(\mathbf{2 7 : 2 8}=5: 3$ by integration of NMR signals) and $\mathbf{2 6 a}(0.125 \mathrm{~g}, 42 \%)$ as colourless oils.

Methyl (4aSR,5RS,12SR,12a $R S)$-12a-hydroxy-12-methyl$1,2,3,4,4 a, 5,6,11,12,-12$ a-decahydro-dibenzo[a,e][8]annulene-5-carboxylate (27): ${ }^{1} \mathrm{H} \mathrm{NMR}\left(\mathrm{CDCl}_{3}, 700 \mathrm{MHz}\right)$ : $\delta=0.80-2.03(\mathrm{~m}, 10 \mathrm{H}, 1-\mathrm{H}, 2-\mathrm{H}, 3-\mathrm{H}, 4-\mathrm{H}, 4 \mathrm{a}-\mathrm{H}, \mathrm{OH}), 1.04$ (d, $J=6.6 \mathrm{~Hz}, 3 \mathrm{H}, 12-\mathrm{Me}), 2.56-2.62(\mathrm{~m}, 1 \mathrm{H}, 12-\mathrm{H}), 2.70$ (dd, $J=11.3,16.8 \mathrm{~Hz}, 1 \mathrm{H}, 11-\mathrm{H}), 2.82(\mathrm{dd}, J=2.2,15.0 \mathrm{~Hz}, 1$ H, 6-H), 2.97 (dd, $J=3.8,16.8 \mathrm{~Hz}, 1 \mathrm{H}, 11-\mathrm{H}), 3.00$ (ddd, $J=$ 2.2, 7.3, 9.6 Hz, $1 \mathrm{H}, 5-\mathrm{H}), 3.61$ (dd, $J=7.3,15.0 \mathrm{~Hz}, 1 \mathrm{H}$, 6-H), 3.63 (s, $3 \mathrm{H}, \mathrm{CO}_{2} \mathrm{Me}$ ), 7.03-7.07, 7.10-7.15 (2 m, $2 \times 2$ $\mathrm{H}, \mathrm{Ar}) \mathrm{ppm}$.

Methyl (4aS,4bR,8aR,9S)-4b-hydroxy-1-[(1E)-prop-1-en-1yl]-2,4a,4b,5,6,7,8,8a,-9,10-decahydro-phenanthrene-9-carboxylate (28): ${ }^{1} \mathrm{H} \mathrm{NMR}\left(\mathrm{CDCl}_{3}, 700 \mathrm{MHz}\right): \delta=0.80-2.03(\mathrm{~m}$, 15 H, 2-H, 5-H, 6-H, 7-H, 8-H, 8a-H, 9-H, 10-H, OH), 1.81 (dd, $J=1.2,6.5 \mathrm{~Hz}, 3 \mathrm{H},=\mathrm{CHMe}), 3.14(\mathrm{dd}, J=3.8,13.3 \mathrm{~Hz}, 1 \mathrm{H}$, 4a-H), 3.72 (s, $\left.3 \mathrm{H}, \mathrm{CO}_{2} \mathrm{Me}\right), 5.66$ (qd, $J=6.5,15.4 \mathrm{~Hz}, 1 \mathrm{H}$, $=\mathrm{C} H \mathrm{Me}), 5.83-5.85,5.90-5.93(2 \mathrm{~m}, 2 \times 1 \mathrm{H}, 3-\mathrm{H}, 4-\mathrm{H}), 6.53$ (br. d, $J=15.4 \mathrm{~Hz}, 1 \mathrm{H}, 1-\mathrm{C} H=$ ) ppm.
Mixture of $27+28:{ }^{13} \mathrm{C} \mathrm{NMR}\left(\mathrm{CDCl}_{3}, 175 \mathrm{MHz}, 40{ }^{\circ} \mathrm{C}\right): \delta=$ $17.3,18.9,20.1,20.7,21.2,24.4,25.2,26.6,27.4,27.6,30.5$, 32.0, 37.3, 40.2, 41.5, 43.0, 44.2, 45.2, 45.3, 51.2, 51.5, 51.9, 75.4 (s, C-4b, 28), 75.9 (s, C-12a, 27), 123.0, 124.7, 126.0, 126.2, 128.0, 129.2 (4 d, 2 s, C-1, C-3, C-4, C-10a, $C H=C H M e$, 28), 125.8, 126.7, 129.5, 132.6, 136.0, 140.4 (4 d, 2 s, Ar, 27), 175.5 (s, C=O, 28), 176.6 (s, C=O, 27) ppm, no unambiguous assignment of signals was possible. IR (neat): $\tilde{\mathrm{v}}=3510(\mathrm{br}$, $\mathrm{OH})$, 3060-2860 (=C-H, C-H), 1720 (br, C=O), $1600(\mathrm{C}=\mathrm{C})$ $\mathrm{cm}^{-1}$. HRMS (ESI) calcd for $\mathrm{C}_{19} \mathrm{H}_{26} \mathrm{O}_{3}:[\mathrm{M}+\mathrm{Na}]^{+}=325.1774$; found: 325.1798 .

\section{$\mathrm{Sml}_{2}$-induced cyclization of $\mathbf{2 6 \mathbf { b }}$}

General procedure A: Compound 26b (0.300 g, $1.00 \mathrm{mmol})$, $\mathrm{SmI}_{2}(2.20 \mathrm{mmol})$, HMPA $(3.16 \mathrm{~mL}, 18.0 \mathrm{mmol})$ and $t$ - $\mathrm{BuOH}(0.148 \mathrm{~g}, 2.00 \mathrm{mmol})$. The crude product was purified by column chromatography (silica gel, ethyl acetate/hexane 1:9) to furnish $29(0.025 \mathrm{~g}, 9 \%)$ as colourless crystals (mp $\left.119-121^{\circ} \mathrm{C}\right), \mathbf{2 3}(0.082 \mathrm{~g}, 27 \%)$ and $\mathbf{2 6 b}(0.120 \mathrm{~g}, 40 \%)$ as colourless oils.

$(4 \mathrm{a} R S, 5 R S, 12 R S, 12 \mathrm{a} S R)-5$-Methyl-1,3,4,5,6,11,12,12aoctahydro- $2 H-4$ a, $12-($ epoxymethano)dibenzo $[a, e][8]-$ annulen-13-one (29): ${ }^{1} \mathrm{H} \mathrm{NMR}\left(\mathrm{CDCl}_{3}, 500 \mathrm{MHz}\right): \delta=0.90$ (d, $J=7.1 \mathrm{~Hz}, 3 \mathrm{H}, 5-\mathrm{Me}$ ), 1.25-1.31, 1.39-1.48, 1.52-1.60, 1.65-1.81 (4 m, $1 \mathrm{H}, 2 \times 2 \mathrm{H}, 3 \mathrm{H}, 1-\mathrm{H}, 2-\mathrm{H}, 3-\mathrm{H}, 4-\mathrm{H})$, 1.97-2.12 (m, $1 \mathrm{H}, 12 \mathrm{a}-\mathrm{H}), 2.19$ (dqd, $J=2.0,7.1,7.2 \mathrm{~Hz}, 1 \mathrm{H}$, 12a-H), 2.57 (dd, $J=7.2,14.6 \mathrm{~Hz}, 1 \mathrm{H}, 6-\mathrm{H}), 2.79$ (br. d, $J \approx$ $14.6 \mathrm{~Hz}, 1 \mathrm{H}, 6-\mathrm{H}), 2.82$ (ddd, $J=1.0,5.2,9.6 \mathrm{~Hz}, 1 \mathrm{H}, 12-\mathrm{H}$ ), $\mathrm{AB}$ part of $\mathrm{ABX}$ system $\left(\delta_{\mathrm{A}}=3.24, \delta_{\mathrm{B}}=3.27, J_{\mathrm{AB}}=15.2 \mathrm{~Hz}\right.$, $\left.J_{\mathrm{AX}}=9.6 \mathrm{~Hz}, J_{\mathrm{BX}}=5.2 \mathrm{~Hz}, 2 \mathrm{H}, 11-\mathrm{H}\right), 7.05-7.07,7.14-7.21$ $(2 \mathrm{~m}, 1 \mathrm{H}, 3 \mathrm{H}, \mathrm{Ar}) \mathrm{ppm} .{ }^{13} \mathrm{C} \mathrm{NMR}\left(\mathrm{CDCl}_{3}, 100 \mathrm{MHz}\right): \delta=$ 15.4 (q, 5-Me), 16.4, 16.5 (2 t, C-2, C-3), 28.6, 28.8 (2 t, C-1, C-4), 35.0 (t, C-6), 35.8 (t, C-11), 42.0 (d, C-5), 47.4 (d, C-12), 91.3 (s, C-4a), 126.7, 126.9, 131.3, 132.1, 137.7, 142.6 (4 d, 2 s, Ar) ppm, the signal for $\mathrm{C}-13$ is not clearly visible. Signals for $\mathrm{C}-2$, C-3, C-5, C-6, C-11, C-12, 5-Me, and three of the aromatic carbon atoms are broad. IR $(\mathrm{KBr}): \tilde{\mathrm{v}}=3045-2870(=\mathrm{C}-\mathrm{H}$, $\mathrm{C}-\mathrm{H}), 1745(\mathrm{C}=\mathrm{O}) \mathrm{cm}^{-1}$. HRMS (ESI) calcd for $\mathrm{C}_{18} \mathrm{H}_{22} \mathrm{O}_{2}$ : $[\mathrm{M}+\mathrm{H}]^{+}=271.1693,[\mathrm{M}+\mathrm{Na}]^{+}=293.1512$; found: 271.1692 , 293.1509 .

\section{$\mathrm{Sml}_{2}$-induced cyclization of $\mathbf{3 0}$}

General procedure B: Compound 30 (0.288 g, $1.00 \mathrm{mmol})$, $\mathrm{SmI}_{2}(2.20 \mathrm{mmol})$, HMPA $(3.16 \mathrm{~mL}, 18.0 \mathrm{mmol})$ and $t$ - $\mathrm{BuOH}(0.148 \mathrm{~g}, 2.00 \mathrm{mmol})$. The crude product was purified by column chromatography (silica gel, ethyl acetate/hexane 1:9) to furnish $31(0.022 \mathrm{~g}, 8 \%)$ as colourless crystals (mp $\left.81-83{ }^{\circ} \mathrm{C}\right), \mathbf{3 2}(0.064 \mathrm{~g}, 31 \%)$ and $\mathbf{3 0}(0.092 \mathrm{~g}, 32 \%)$ as colourless oils. 
Methyl (6RS,8RS,9RS)-8-hydroxy-8-isopropyl-9-methyl$5,6,7,8,9,10$-hexahydro-benzo $[8]$ annulene-6-carboxylate (31): Compound 31 shows temperature-dependent spectra. At rt most signals appear very broad; for measurements at $55^{\circ} \mathrm{C}$, the signals are clearly seen. ${ }^{1} \mathrm{H} \mathrm{NMR}\left(\mathrm{CDCl}_{3}, 500 \mathrm{MHz}, 55^{\circ} \mathrm{C}\right): \delta$ $=0.89,0.90(2 \mathrm{~d}, J=6.8 \mathrm{~Hz}, 2 \times 3 \mathrm{H}, \mathrm{CHMe}), 0.94(\mathrm{~d}, J=7.0$ $\mathrm{Hz}, 3 \mathrm{H}, 9-\mathrm{Me}$ ), 1.49-1.65 (m, $1 \mathrm{H}, 7-\mathrm{H}), 1.62$ (sept, $J=6.8 \mathrm{~Hz}$, $\left.1 \mathrm{H}, \mathrm{C} H \mathrm{Me}_{2}\right), 1.71-1.82(\mathrm{~m}, 1 \mathrm{H}, 7-\mathrm{H}), 2.04-2.11(\mathrm{~m}, 1 \mathrm{H}$, 9-H), 2.57 (dd, $J=8.4,13.2 \mathrm{~Hz}, 1 \mathrm{H}, 10-\mathrm{H}), 2.87-2.97$ (m, $1 \mathrm{H}$, 6-H), 3.07 (dd, $J=5.9,13.7 \mathrm{~Hz}, 1 \mathrm{H}, 5-\mathrm{H}), 3.03-3.14$ (m, $1 \mathrm{H}$, 10-H), 3.24-3.35 (m, $1 \mathrm{H}, 5-\mathrm{H}), 3.72\left(\mathrm{~s}, 3 \mathrm{H}, \mathrm{CO}_{2} \mathrm{Me}\right)$, 7.07-7.09, 7.13-7.18 (2 m, $1 \mathrm{H}, 3 \mathrm{H}, \mathrm{Ar}) \mathrm{ppm}$, the signal for the $\mathrm{OH}$ group could not be assigned unambiguously. ${ }^{13} \mathrm{C}$ NMR $\left(\mathrm{CDCl}_{3}, 125 \mathrm{MHz}, 55{ }^{\circ} \mathrm{C}\right): \delta=15.4$ (q, 9-Me), 16.3, 16.5 (2 q, $\mathrm{CHMe}_{2}$ ), 36.7 (d, $\mathrm{CHMe}_{2}$ ), 42.8 (d, C-9), 65.9 (s, C-8), 126.7, 127.0, 130.7, 130.8, 138.6, 139.9 (4 d, 2 s, Ar), 51.7, 176.5 (q, $\left.\mathrm{s}, \mathrm{CO}_{2} \mathrm{Me}\right) \mathrm{ppm}$. The signals for C-5, C-6 and C-7 are not clearly visible, the signals for $\mathrm{C}-9$ and $9-\mathrm{Me}$ are broad. IR $(\mathrm{KBr}): \tilde{v}=3490(\mathrm{br}, \mathrm{O}-\mathrm{H}), 3060-2850$ (=C-H, C-H), 1710 $(\mathrm{C}=\mathrm{O}) \mathrm{cm}^{-1}$. HRMS (ESI) calcd for $\mathrm{C}_{18} \mathrm{H}_{26} \mathrm{O}_{3}:[\mathrm{M}+\mathrm{Na}]^{+}=$ 313.1774; found: 313.1773 .

Methyl 3-\{2-[(1Z)-propen-1-yl]phenyl\}propanoate (32): ${ }^{1} \mathrm{H} \mathrm{NMR}\left(\mathrm{CDCl}_{3}, 250 \mathrm{MHz}\right): \delta=1.72(\mathrm{dd}, J=1.6,7.0 \mathrm{~Hz}, 3 \mathrm{H}$, $=\mathrm{CHMe}), 2.54(\mathrm{t}, J=8.2 \mathrm{~Hz}, 2 \mathrm{H}, 2-\mathrm{H}), 2.92(\mathrm{t}, J=8.2 \mathrm{~Hz}, 2 \mathrm{H}$, $3-\mathrm{H}), 3.66$ (s, $3 \mathrm{H}, \mathrm{CO}_{2} \mathrm{Me}$ ), 5.85 (qd, $J=7.0,11.5 \mathrm{~Hz}, 1 \mathrm{H}$, $=\mathrm{C} H \mathrm{Me}), 6.52(\mathrm{qd}, J=1.6,11.5 \mathrm{~Hz}, 1 \mathrm{H},=\mathrm{C} H A r), 7.18$ (br. s, 4 $\mathrm{H}$, Ar) ppm. ${ }^{13} \mathrm{C} \mathrm{NMR}\left(\mathrm{CDCl}_{3}, 125 \mathrm{MHz}\right): \delta=14.4$ (q, $=\mathrm{CHMe}$ ), 28.8 (t, C-3), 34.8 (t, C-2), 126.1, 127.1, 127.8, 128.4, 129.0, 129.8, 136.4, 138.7 (6 d, $2 \mathrm{~s}, \mathrm{ArCH}=\mathrm{CH}), 51.7,173.6$ (q, s, $\left.\mathrm{CO}_{2} \mathrm{Me}\right)$ ppm. IR (neat): $\tilde{\mathrm{v}}=3065-2870(=\mathrm{C}-\mathrm{H}, \mathrm{C}-\mathrm{H}), 1735$ $(\mathrm{C}=\mathrm{O}) \mathrm{cm}^{-1}$. MS (EI, $\left.70 \mathrm{eV}\right): \mathrm{m} / z(\%)=204(56)[\mathrm{M}]^{+}, 144$ (36), 129 (100), 115 (88), 91 (51), 77 (19), 18 (70); HRMS (80 eV) calcd for $\mathrm{C}_{13} \mathrm{H}_{16} \mathrm{O}_{2}:[\mathrm{M}]^{+}=204.11504$; found: 204.11464.

\section{$\mathrm{Sml}_{2}$-induced cyclization of $\mathbf{3 3}$}

General procedure B: Compound $33(0.314 \mathrm{~g}, 1.00 \mathrm{mmol})$, $\mathrm{SmI}_{2}(2.20 \mathrm{mmol})$, HMPA $(3.16 \mathrm{~mL}, 18.0 \mathrm{mmol})$ and $t$-BuOH $(0.148 \mathrm{~g}, 2.00 \mathrm{mmol})$. The crude product was purified by column chromatography (silica gel, ethyl acetate/hexane 1:9) to furnish $34(0.075 \mathrm{~g}, 24 \%)$ as colourless crystals (mp $131-133{ }^{\circ} \mathrm{C}$ ) and $35(0.109 \mathrm{~g}, 47 \%)$ as a colourless oil.

Methyl (6RS,8RS,9RS)-9-cyclopropyl-8-hydroxy-8-isopropyl-5,6,7,8,9,10-hexahydro-benzo[8]annulene-6-carboxylate (34): Compound 35 shows temperature-dependent spectra. At rt most signals appear very broad; however, for measurements at $51{ }^{\circ} \mathrm{C}$, the signals are clearly seen. ${ }^{1} \mathrm{H}$ NMR $\left(\mathrm{CDCl}_{3}, 500 \mathrm{MHz}, 51{ }^{\circ} \mathrm{C}\right): \delta=0.27-0.32,0.47-0.57$, 0.62-0.69 (3 m, 1 H, 3 H, 1 H, 1'-H, 2'-H, 3'-H), 0.90, 0.98 (2 d,
$\left.J=6.7 \mathrm{~Hz}, 2 \times 3 \mathrm{H}, \mathrm{CHMe} e_{2}\right), 1.12(\mathrm{~s}, 1 \mathrm{H}, \mathrm{OH}), 1.28-1.33(\mathrm{~m}$, $1 \mathrm{H}, 9-\mathrm{H}), 1.60-1.68,1.87-1.91(2 \mathrm{~m}, 2 \times 1 \mathrm{H}, 7-\mathrm{H}), 2.06$ (sept, $\left.J=6.7 \mathrm{~Hz}, 1 \mathrm{H}, \mathrm{C} H \mathrm{Me}_{2}\right), 2.68(\mathrm{dd}, J=6.9,13.9 \mathrm{~Hz}, 1 \mathrm{H}$, 10-H), 2.94-2.99 (m, $1 \mathrm{H}, 6-\mathrm{H}), 3.07$ (dd, $J=4.1,13.9 \mathrm{~Hz}, 1 \mathrm{H}$, 10-H), 3.18-3.21 (m, $1 \mathrm{H}, 5-\mathrm{H}), 3.41$ (dd, $J=5.6,13.7 \mathrm{~Hz}, 1 \mathrm{H}$, 5-H), 3.71 (s, $\left.3 \mathrm{H}, \mathrm{CO}_{2} \mathrm{Me}\right), 7.04-7.07,7.11-7.15,7.26-7.30$ (3 m, $1 \mathrm{H}, 2 \mathrm{H}, 1 \mathrm{H}, \mathrm{Ar}) \mathrm{ppm} .{ }^{13} \mathrm{C} \mathrm{NMR}\left(\mathrm{CDCl}_{3}, 125 \mathrm{MHz}, 51\right.$ $\left.{ }^{\circ} \mathrm{C}\right): \delta=3.8,6.6\left(2 \mathrm{t}, \mathrm{C}-2^{\prime}, \mathrm{C}-3{ }^{\prime}\right), 11.7\left(\mathrm{~d}, \mathrm{C}-1^{\prime}\right), 17.1,17.3$ (2 q, $\mathrm{CHMe}$ ), 34.8, 35.2, 35.9 (d, 2 t, $\mathrm{CHMe}_{2}, \mathrm{C}-5, \mathrm{C}-10$ ), 41.9 (d, C-6), 51.4 (d, C-9), 77.7 (s, C-8), 126.2, 126.5, 130.3, 131.0, $138.1,140.2$ (4 d, $2 \mathrm{~s}, \mathrm{Ar}$ ), 51.8, 176.5 (q, s, $\mathrm{CO}_{2} \mathrm{Me}$ ) ppm, the signal for $\mathrm{C}-7$ is not clearly visible, the signals for $\mathrm{C}-5, \mathrm{C}-8$, C-9, C-10, C-1', C-2', C-3', $\mathrm{CHMe}_{2}$, Ar (2 d, 2 s) are broad. IR $(\mathrm{KBr}): \tilde{v}=3490$ (br, O-H), 3080-2875 (=C-H, C-H), 1715 $(\mathrm{C}=\mathrm{O}) \mathrm{cm}^{-1} \cdot \mathrm{C}_{20} \mathrm{H}_{28} \mathrm{O}_{3}$ (316.4): calcd: C 75.91, $\mathrm{H} \mathrm{8.92}$; found: C 76.09, H 8.88.

Methyl 3-\{2-[(E)-2-cyclopropylvinyl $]$ phenyl\}propanoate (35): ${ }^{1} \mathrm{H} \mathrm{NMR}\left(\mathrm{CDCl}_{3}, 500 \mathrm{MHz}\right): \delta=0.82-0.91$ (m, $4 \mathrm{H}, 2^{\prime}-\mathrm{H}$, $\left.3^{\prime}-\mathrm{H}\right), 1.61\left(\mathrm{ttd}, J=4.5,8.5,8.9 \mathrm{~Hz}, 1 \mathrm{H}, 1^{\prime}-\mathrm{H}\right), 2.59$ (t, $J=$ $8.2 \mathrm{~Hz}, 2 \mathrm{H}, 2-\mathrm{H}), 3.02$ (t, $J=8.2 \mathrm{~Hz}, 2 \mathrm{H}, 3-\mathrm{H}), 3.70$ (s, $3 \mathrm{H}$, $\left.\mathrm{CO}_{2} \mathrm{Me}\right), 5.60\left(\mathrm{dd}, J=8.9,15.5 \mathrm{~Hz}, 1 \mathrm{H}, 1^{\prime}-\mathrm{CH}=\right), 6.69(\mathrm{~d}, J=$ $15.5 \mathrm{~Hz}, 1 \mathrm{H},=\mathrm{CHAr}), 7.12-7.18,7.36-7.39(2 \mathrm{~m}, 3 \mathrm{H}, 1 \mathrm{H}$, Ar) ppm. ${ }^{13} \mathrm{C} \mathrm{NMR}\left(\mathrm{CDCl}_{3}, 125 \mathrm{MHz}\right): \delta=7.5$ (t, C-2', C-3'), 15.0 (d, C-1'), 28.6 (t, C-2), 35.2 (t, C-3), 124.4 (d, =CHAr), $137.2\left(\mathrm{~d}, 1^{\prime}-\mathrm{CH}=\right), 125.8,126.8,126.9,129.3,136.6,137.0(4 \mathrm{~d}$, $2 \mathrm{~s}, \mathrm{Ar}), 51.8,173.6$ (q, s, $\mathrm{CO}_{2} \mathrm{Me}$ ) ppm. HRMS (ESI) calcd for $\mathrm{C}_{15} \mathrm{H}_{18} \mathrm{O}_{2}$ : $[\mathrm{M}+\mathrm{Na}]^{+}=253.1199$; found: 253.1201 .

\section{$\mathrm{Sml}_{2}$-induced cyclization of $\mathbf{3 6}$}

General procedure B: Compound 36 (0.200 g, $0.57 \mathrm{mmol})$, $\mathrm{SmI}_{2}(1.26 \mathrm{mmol})$, HMPA $(1.80 \mathrm{~mL}, 10.3 \mathrm{mmol})$ and $t$-BuOH (0.085 g, $1.15 \mathrm{mmol})$. The crude product was purified by column chromatography (silica gel, ethyl acetate/hexane 1:9) to furnish $37(0.094 \mathrm{~g}, 47 \%)$ as colourless crystals (mp $\left.135-137{ }^{\circ} \mathrm{C}\right)$ and $\mathbf{3 6}(0.040 \mathrm{~g}, 20 \%)$ as a colourless oil.

\section{Methyl (6RS,8RS,9RS)-8-hydroxy-8-isopropyl-9-phenyl-} $\mathbf{5 , 6 , 7 , 8 , 9 , 1 0 - h e x a h y d r o - b e n z o}[8]$ annulene-6-carboxylate (37): ${ }^{1} \mathrm{H} \mathrm{NMR}\left(\mathrm{CDCl}_{3}, 500 \mathrm{MHz}\right): \delta=1.07$ (br. s, $\left.1 \mathrm{H}, \mathrm{OH}\right)$, $1.10,1.17(2 \mathrm{~d}, J=6.8 \mathrm{~Hz}, 2 \times 3 \mathrm{H}, \mathrm{CHMe}), 2.06(\mathrm{dd}, J=$ 12.4, 14.2 Hz, $1 \mathrm{H}, 7-\mathrm{H}$ ), 2.07 (sept, $J=6.8 \mathrm{~Hz}, 1 \mathrm{H}, \mathrm{CHMe}$ ), 2.40-2.44 (m, $1 \mathrm{H}, 7-\mathrm{H}), 2.81$ (dddd, $J=1.8,2.6,12.3,12.4 \mathrm{~Hz}$, $1 \mathrm{H}, 6-\mathrm{H}), 2.91(\mathrm{dd}, J=3.0,13.1 \mathrm{~Hz}, 1 \mathrm{H}, 10-\mathrm{H}), 3.02(\mathrm{dd}, J=$ $1.8,14.8 \mathrm{~Hz}, 1 \mathrm{H}, 5-\mathrm{H}), 3.08$ (dd, $J=11.9,13.1 \mathrm{~Hz}, 1 \mathrm{H}, 10-\mathrm{H})$, $3.21(\mathrm{dd}, J=3.0,11.9 \mathrm{~Hz}, 1 \mathrm{H}, 9-\mathrm{H}), 3.44(\mathrm{dd}, J=12.3,14.8$ $\mathrm{Hz}, 1 \mathrm{H}, 5-\mathrm{H}), 3.74\left(\mathrm{~s}, 3 \mathrm{H}, \mathrm{CO}_{2} \mathrm{Me}\right), 6.52-6.54,6.75-6.77$, 6.85-6.88, 7.04-7.14 (4 m, $1 \mathrm{H}, 2 \mathrm{H}, 1 \mathrm{H}, 5 \mathrm{H}$, Ar) ppm. ${ }^{13} \mathrm{C} \mathrm{NMR}\left(\mathrm{CDCl}_{3}, 125 \mathrm{MHz}\right): \delta=17.5,17.7\left(2 \mathrm{q}, \mathrm{CHMe} e_{2}\right.$, 35.2 (t, C-10), 35.3 (d, $\mathrm{CHMe}_{2}$ ), 38.3 (t, C-5), 38.5 (t, C-7), 
40.5 (d, C-6), 57.8 (d, C-9), 74.2 (s, C-8), 125.9, 126.5, 127.5, 128.1, 128.9, 130.9, 134.4, 137.6, 139.4, 140.5 (7 d, 3 s, Ar), $52.1,176.8$ (q, s, $\left.\mathrm{CO}_{2} \mathrm{Me}\right) \mathrm{ppm}$. IR $(\mathrm{KBr}): \widetilde{v}=3485$ (br, O-H), 3100-2845 (=C-H, C-H), $1710(\mathrm{C}=\mathrm{O}) \mathrm{cm}^{-1}$. MS (EI = $\left.70 \mathrm{eV}\right)$ : $m / z(\%)=352(41)[\mathrm{M}]^{+}, 309(15), 267$ (22), 157 (70), 91 (100), 71 (40), 43 (95). $\mathrm{C}_{23} \mathrm{H}_{28} \mathrm{O}_{3}$ (352.5): calcd C 78.38, H 8.01; found: C 78.05, H 8.04 .

\section{$\mathrm{Sml}_{2}$-induced cyclization of $\mathbf{3 8 a}$}

General procedure A: Compound 38a $(0.170 \mathrm{~g}, 0.47 \mathrm{mmol})$, $\mathrm{SmI}_{2}(1.04 \mathrm{mmol})$, HMPA $(1.48 \mathrm{~mL}, 8.43 \mathrm{mmol})$ and $t$-BuOH $(0.070 \mathrm{~g}, 0.94 \mathrm{mmol})$. The crude product was purified by column chromatography (silica gel, ethyl acetate/hexane 1:9), then HPLC (ethyl acetate/hexane 15:85) to furnish 39 (0.074 g, $44 \%$ ) as colourless crystals ( $\mathrm{mp} 114-115^{\circ} \mathrm{C}$ ).

Methyl (4aSR,5SR,11RS,11aSR)-5-benzyl-4a-hydroxy2,3,4,4a,5,10,11,11a-octahydro-1 $H$-dibenzo $[a, d][7]$ annulene11-carboxylate (39): ${ }^{1} \mathrm{H} \mathrm{NMR}\left(\mathrm{CDCl}_{3}, 500 \mathrm{MHz}\right): \delta=1.10(\mathrm{~s}$, $1 \mathrm{H}, \mathrm{OH}), 1.24-1.36,1.42-1.51,1.59-1.64,1.66-1.75$, 2.01-2.08 (5 m, 2 H, 2 × 1 H, 3 H, 1 H, 1-H, 2-H, 3-H, 4-H), 2.24 (ddd, $J=3.7,11.2,11.4 \mathrm{~Hz}, 1 \mathrm{H}, 11 \mathrm{a}-\mathrm{H}), 2.56$ (ddd, $J=$ 1.6, 11.2, $12.2 \mathrm{~Hz}, 1 \mathrm{H}, 11-\mathrm{H}), 2.75$ (dd, $J=1.6,15.0 \mathrm{~Hz}, 1 \mathrm{H}$, $10-\mathrm{H}), 2.81$ (dd, $J=3.3,11.2 \mathrm{~Hz}, 1 \mathrm{H}, 5-\mathrm{H}), \mathrm{AB}$ part of ABX $\operatorname{system}\left(\delta_{\mathrm{A}}=3.11, \delta_{\mathrm{B}}=3.19, J_{\mathrm{AB}}=13.3 \mathrm{~Hz}, J_{\mathrm{AX}}=3.3 \mathrm{~Hz}, J_{\mathrm{BX}}\right.$ $\left.=11.2 \mathrm{~Hz}, 2 \mathrm{H}, \mathrm{PhCH}_{2}\right), 3.57(\mathrm{dd}, J=12.2,15.0 \mathrm{~Hz}, 1 \mathrm{H}$, $10-\mathrm{H}), 3.73$ (s, $3 \mathrm{H}, \mathrm{CO}_{2} \mathrm{Me}$ ), 6.54-6.56, 6.81-6.83, 6.87-6.91, 7.05-7.12 (4 m, $1 \mathrm{H}, 2 \mathrm{H}, 1 \mathrm{H}, 5 \mathrm{H}, \mathrm{Ar}) \mathrm{ppm}$, the signal for the $\mathrm{OH}$ group could not be assigned unambiguously. ${ }^{13} \mathrm{C}$ NMR $\left(\mathrm{CDCl}_{3}, 125 \mathrm{MHz}\right): \delta=21.9(\mathrm{t}, \mathrm{C}-3), 25.8(\mathrm{t}, \mathrm{C}-2), 28.5(\mathrm{t}$, $\mathrm{C}-1), 35.7$ (t, $\mathrm{PhCH}_{2}$ ), 38.6 (t, C-10), 39.7 (t, C-4), 44.7 (d, C-11a), 47.8 (d, C-11), 64.9 (d, C-5), 72.7 (s, C-4a), 125.9, $126.7,127.5,128.1,128.9,130.6,133.7,138.1,138.6,141.0(7$ d, 3 s, Ar), 51.7, 176.6 (q, s, $\mathrm{CO}_{2} \mathrm{Me}$ ) ppm. IR (KBr): $\widetilde{v}=3430$ (br, O-H), 3055-2845 (=C-H, C-H), $1705(\mathrm{C}=\mathrm{O}) \mathrm{cm}^{-1}$. MS (EI $=70 \mathrm{eV}): m / z(\%)=364(4)[\mathrm{M}]^{+}, 267$ (39), 169 (39), 115 (23), 91 (100), 41 (10). HRMS (80 eV) calcd for $\mathrm{C}_{24} \mathrm{H}_{28} \mathrm{O}_{3}$ : $[\mathrm{M}]^{+}=$ 364.2039; found: 364.2034 .

\section{$\mathrm{Sml}_{2}$-induced cyclization of $\mathbf{3 8 b}$}

General procedure A: Compound 38b (0.145 g, $0.40 \mathrm{mmol})$, $\mathrm{SmI}_{2}(0.88 \mathrm{mmol})$, HMPA $(1.27 \mathrm{~mL}, 7.23 \mathrm{mmol})$ and $t$-BuOH $(0.059 \mathrm{~g}, 0.80 \mathrm{mmol})$. The crude product was purified by column chromatography (silica gel, ethyl acetate/hexane 1:9) to furnish $40(0.084 \mathrm{~g}, 63 \%)$ as colourless crystals (mp 193-195 $\left.{ }^{\circ} \mathrm{C}\right)$.

$(4 \mathrm{a} R S, 5 R S, 11 R S, 11 \mathrm{a} R S)-5$-Benzyl-1,2,3,4,5,10,11,11 aoctahydro-4a,11-(epoxy-methano)-dibenzo[ $a, d][7]$ annulen12-one (40): ${ }^{1} \mathrm{H}$ NMR $\left(\mathrm{CDCl}_{3}, 500 \mathrm{MHz}\right): \delta=1.11-1.29$, $1.47-1.56,1.71-1.75,1.95-2.03,2.19-2.23(5 \mathrm{~m}, 2 \mathrm{H}, 1 \mathrm{H}, 2 \times$
$2 \mathrm{H}, 1 \mathrm{H}, 1-\mathrm{H}, 2-\mathrm{H}, 3-\mathrm{H}, 4-\mathrm{H}), 2.54$ (dd, $J=6.6,11.4 \mathrm{~Hz}, 1 \mathrm{H}$, $11 \mathrm{a}-\mathrm{H}), 2.65\left(\mathrm{dd}, J=11.3,12.8 \mathrm{~Hz}, 1 \mathrm{H}, \mathrm{PhCH}_{2}\right), 2.71(\mathrm{dd}, J=$ 2.6, $6.6 \mathrm{~Hz}, 1 \mathrm{H}, 11-\mathrm{H}), 2.94(\mathrm{dd}, J=2.4,12.8 \mathrm{~Hz}, 1 \mathrm{H}$, $\left.\mathrm{PhCH}_{2}\right), 3.02(\mathrm{dd}, J=2.4,11.3 \mathrm{~Hz}, 1 \mathrm{H}, 5-\mathrm{H}), 3.23-3.31$ (m, 2 $\mathrm{H}, 10-\mathrm{H}), 6.29-6.31,6.71-6.74,6.81-6.85,7.04-7.07$, 7.11-7.15 (5 m, $1 \mathrm{H}, 2 \mathrm{H}, 2 \times 1 \mathrm{H}, 4 \mathrm{H}, \mathrm{Ar}) \mathrm{ppm} .{ }^{13} \mathrm{C} \mathrm{NMR}$ $\left(\mathrm{CDCl}_{3}, 125 \mathrm{MHz}\right): \delta=21.5(\mathrm{t}, \mathrm{C}-3), 23.6(\mathrm{t}, \mathrm{C}-2), 29.9(\mathrm{t}$, C-1), 33.7 (t, C-4), 36.6 (t, C-10), 39.6 (t, $\mathrm{PhCH}_{2}$ ), 43.5 (d, C-11a), 49.5 (d, C-5), 62.4 (d, C-11), 86.0 (s, C-4a), 126.3, $126.5,127.1,128.2,129.2,131.2,133.3,135.5,137.6,139.6(7$ d, 3 s, Ar), 178.2 (s, C-12) ppm. IR (neat): $\tilde{\mathrm{v}}=3060-2855$ (=C$\mathrm{H}, \mathrm{C}-\mathrm{H}), 1760(\mathrm{C}=\mathrm{O}) \mathrm{cm}^{-1} . \mathrm{C}_{23} \mathrm{H}_{24} \mathrm{O}_{2}$ (332.4): calcd: $\mathrm{C} 83.10$, H 7.28; found: C 82.64, H 7.08.

\section{$\mathrm{Sml}_{2}$-induced cyclization of $\mathbf{4 1}$}

General procedure A: Compound 41 (0.223 g, $0.81 \mathrm{mmol})$, $\mathrm{SmI}_{2}(1.80 \mathrm{mmol})$, HMPA $(2.56 \mathrm{~mL}, 14.6 \mathrm{mmol})$ and $t$-BuOH $(0.120 \mathrm{~g}, 1.62 \mathrm{mmol})$. The crude product was purified by column chromatography (silica gel, ethyl acetate/hexane 1:9), then HPLC (ethyl acetate/hexane 1:5) to furnish $42(0.031 \mathrm{~g}$, $14 \%)$ and $43(0.014 \mathrm{~g}, 7 \%)$ as colourless oils.

Methyl (2SR,4RS,4aSR)-4-hydroxy-4-methyl-8-(2-methylpropen-1-yl)-1,2,3,4,4a,7-hexahydro-naphthalene-2-carboxylate (42): ${ }^{1} \mathrm{H} \mathrm{NMR}\left(\mathrm{CDCl}_{3}, 500 \mathrm{MHz}\right): \delta=1.08(\mathrm{~s}, 3 \mathrm{H}$, 4-Me), 1.54, $1.74\left(2 \mathrm{~s}, 2 \times 3 \mathrm{H},=\mathrm{CMe}_{2}\right), 1.75-1.82(\mathrm{~m}, 2 \mathrm{H}$, 1-H, 3-H), 2.04 (ddd, $J=1.8,3.8,12.5 \mathrm{~Hz}, 1 \mathrm{H}, 3-\mathrm{H}), 2.38$ (tt, $J$ $=3.8,12.9 \mathrm{~Hz}, 1 \mathrm{H}, 2-\mathrm{H}), 2.50-2.62(\mathrm{~m}, 2 \mathrm{H}, 7-\mathrm{H}), 2.71-2.77$ (m, $2 \mathrm{H}, 1-\mathrm{H}, 4 \mathrm{a}-\mathrm{H}), 3.67$ (s, $3 \mathrm{H}, \mathrm{CO}_{2} \mathrm{Me}$ ), 5.50 (br. s, $1 \mathrm{H}$, $\left.\mathrm{CH}=\mathrm{CMe}_{2}\right), 5.82-5.88(\mathrm{~m}, 2 \mathrm{H}, 5-\mathrm{H}, 6-\mathrm{H}) \mathrm{ppm}$, the signal for the $\mathrm{OH}$ group could not be assigned unambiguously. ${ }^{13} \mathrm{C} \mathrm{NMR}$ $\left(\mathrm{CDCl}_{3}, 125 \mathrm{MHz}\right): \delta=19.5,25.3(2 \mathrm{q},=\mathrm{CMe} 2), 22.3$ (q, 4-Me), 31.5 (t, C-7), 32.6 (t, C-1), 40.5 (d, C-2), 44.0 (t, C-3), 49.3 (d, C-4a), 74.2 (s, C-4), 123.7, 124.7, 125.9, 127.5, $128.8,134.2\left(3 \mathrm{~d}, 3 \mathrm{~s},=\mathrm{CH},=\mathrm{C}_{\mathrm{q}}\right), 51.9,175.5\left(\mathrm{q}, \mathrm{s}, \mathrm{CO}_{2} \mathrm{Me}\right)$ ppm.

(1SR,4SR,9aSR)-1-Methyl-6-(2-methylpropen-1-yl)-4,5,7,9atetrahydro-1,4-methano-2-benzoxepin-3(1H)-one $\mathbf{( 4 3 )}$ : ${ }^{1} \mathrm{H} \mathrm{NMR}\left(\mathrm{CDCl}_{3}, 500 \mathrm{MHz}\right): \delta=1.51,1.76(2 \mathrm{~s}, 2 \times 3 \mathrm{H}$, $\left.=\mathrm{CMe}_{2}\right), 1.54(\mathrm{~s}, 3 \mathrm{H}, 4-\mathrm{Me}), \mathrm{AB}$ part of $\mathrm{ABX}$ system $\left(\delta_{\mathrm{A}}=\right.$ $1.86, \delta_{\mathrm{B}}=1.91, J_{\mathrm{AB}}=11.5 \mathrm{~Hz}, J_{\mathrm{AX}}=4.7 \mathrm{~Hz}, J_{\mathrm{BX}}$ too small to see signal splitting, $2 \mathrm{H}, 10-\mathrm{H}), 2.22-2.27(\mathrm{~m}, 1 \mathrm{H}, 5-\mathrm{H})$, 2.52-2.67 (m, 3 H, 5-H, 7-H), 2.84-2.90 (m, $1 \mathrm{H}, 4-\mathrm{H})$, 3.16-3.20 (m, $1 \mathrm{H}, 9 \mathrm{a}-\mathrm{H}), 5.49$ (br. s, $1 \mathrm{H}, \mathrm{CH}=\mathrm{CMe}_{2}$ ), 5.74-5.78, 5.84-5.88 (2 m, $2 \times 1 \mathrm{H}, 8-\mathrm{H}, 9-\mathrm{H}) \mathrm{ppm}$, the signal for the $\mathrm{OH}$ group could not be assigned unambiguously. ${ }^{13} \mathrm{C} \mathrm{NMR}\left(\mathrm{CDCl}_{3}, 125 \mathrm{MHz}\right): \delta=19.7,25.4\left(2 \mathrm{q},=\mathrm{CMe}_{2}\right)$, 23.7 (q, 1-Me), 30.1 (t, C-5), 31.6 (t, C-7), 37.1, 37.9 (2 d, C-4, C-9a), 45.3 (t, C-10), 88.7 (s, C-1), 123.9, 124.2, 124.4, 126.8, $131.9,136.1\left(3 \mathrm{~d}, 3 \mathrm{~s},=\mathrm{CH},=\mathrm{C}_{\mathrm{q}}\right), 180.9(\mathrm{~s}, \mathrm{C}-3) \mathrm{ppm}$. 


\section{Supporting Information}

\section{Supporting Information File 1}

Experimental procedures and characterization data of synthesized compounds.

Supporting Information File 1 contains all experimental procedures for the syntheses of the starting materials 2,4 , $5,7,11,14,16,18,21,24,26,30,33,36,38$, and 41 and their analytical data.

[http://www.beilstein-journals.org/bjoc/content/ supplementary/1860-5397-6-141-S1.pdf]

\section{Acknowledgments}

Generous support of this work by the Deutsche Forschungsgemeinschaft, the Fonds der Chemischen Industrie and the Bayer Schering Pharma AG is most gratefully acknowledged. We also thank Dr. R. Zimmer and Dr. C. Beemelmanns for their help during preparation of this manuscript.

\section{References}

1. Mehta, G.; Singh, V. Chem. Rev. 1999, 99, 881-930. doi:10.1021/cr9800356

2. Petasis, N. A.; Patane, M. A. Tetrahedron 1992, 48, 5757-5821. doi:10.1016/S0040-4020(01)90172-3

3. Galli, C.; Mandolini, L. Eur. J. Org. Chem. 2000, 3117-3125. doi:10.1002/1099-0690(200009)2000:18<3117::AID-EJOC3117>3.0.C $0 ; 2-5$

4. Nicolaou, K. C.; Bulger, P. G.; Sarlah, D. Angew. Chem., Int. Ed. 2005, 44, 4490-4527. doi:10.1002/anie.200500369

5. Fujiwara, K.; Goto, A.; Sato, D.; Kawai, H.; Suzuki, T. Tetrahedron Lett. 2005, 46, 3465-3468. doi:10.1016/j.tetlet.2005.03.114

6. Nair, V.; Abhilash, K. G. Synlett 2008, 301-312. doi:10.1055/s-2008-1032058

7. Ohno, H.; Hamaguchi, H.; Ohata, M.; Kosaka, S.; Tanaka, T. J. Am. Chem. Soc. 2004, 126, 8744-8754. doi:10.1021/ja048693x

8. Yu, Z.-X.; Wang, Y.; Wang, Y. Chem.-Asian J. 2010, 5, 1072-1088. doi:10.1002/asia.200900712

9. Genrich, F.; Schaumann, E. Tetrahedron Lett. 2009, 50, 6187-6190. doi:10.1016/j.tetlet.2009.08.092

10. Zhang, T.; Huang, X.; Xue, J.; Sun, S. Tetrahedron Lett. 2009, 50, 1290-1294. doi:10.1016/j.tetlet.2009.01.001

11. Evans, P. A.; Holmes, B. Tetrahedron 1991, 47, 9131-9166. doi:10.1016/S0040-4020(01)96203-9

12. Roxburgh, C. J. Tetrahedron 1993, 49, 10749-10784. doi:10.1016/S0040-4020(01)80232-5

13. Rousseau, G. Tetrahedron 1995, 51, 2777-2849. doi:10.1016/0040-4020(94)01064-7

14. Hoberg, J. O. Tetrahedron 1998, 54, 12631-12670. doi:10.1016/S0040-4020(98)00596-1

15. Yet, L. Tetrahedron 1999, 55, 9349-9403. doi:10.1016/S0040-4020(99)00483-4

16. Yet, L. Chem. Rev. 2000, 100, 2963-3008. doi:10.1021/cr990407q

17. Nubbemeyer, U. Top. Curr. Chem. 2001, 216, 125-196. doi:10.1007/3-540-44726-1_4

18. Shiina, I. Chem. Rev. 2007, 107, 239-273. doi:10.1021/cr050045o
19. Molander, G. A. Acc. Chem. Res. 1998, 31, 603-609. doi:10.1021/ar960101v

20. Berndt, M.; Gross, S.; Hölemann, A.; Reissig, H.-U. Synlett 2004, 422-438. doi:10.1055/s-2004-815429

21. Procter, D. J.; Flowers, R. A., II; Skrydstrup, T. Organic Synthesis using Samarium Diiodide; Royal Society of Chemistry: Cambridge, U.K., 2009.

22. Molander, G. A.; McKie, J. A. J. Org. Chem. 1994, 59, 3186-3192. doi:10.1021/jo00090a041

23. Molander, G. A.; Alonso-Alija, C. J. Org. Chem. 1998, 63, 4366-4373. doi:10.1021/jo980119e

24. Molander, G. A.; Machrouhi, F. J. Org. Chem. 1999, 64, 4119-4123. doi:10.1021/jo990216n

25. Molander, G. A.; Köllner, C. J. Org. Chem. 2000, 65, 8333-8339. doi:10.1021/jo001195w

26. Molander, G. A.; Le Huérou, Y.; Brown, G. A. J. Org. Chem. 2001, 66, 4511-4516. doi:10.1021/jo001513r

27. Molander, G. A.; Brown, G. A.; Storch de Gracia, I. J. Org. Chem. 2002, 67, 3459-3463. doi:10.1021/jo020027w

28. Inanaga, J.; Yokoyama, Y.; Handa, Y.; Yamaguchi, M. Tetrahedron Lett. 1991, 32, 6371-6374. doi:10.1016/0040-4039(91)80172-3

29. Matsuda, F.; Sakai, T.; Okada, N.; Miyashita, M. Tetrahedron Lett. 1998, 39, 863-864. doi:10.1016/S0040-4039(97)10750-X

30. Tamiya, H.; Goto, K.; Matsuda, F. Org. Lett. 2004, 6, 545-547. doi:10.1021/ol036329h

31. Khan, F. A.; Czerwonka, R.; Zimmer, R.; Reissig, H.-U. Synlett 1997, 995-997. doi:10.1055/s-1997-934

32. Nandanan, E.; Dinesh, C. U.; Reissig, H.-U. Tetrahedron 2000, 56, 4267-4277. doi:10.1016/S0040-4020(00)00353-7

33. Reissig, H.-U.; Khan, F. A.; Czerwonka, R.; Dinesh, C. U.; Shaikh, A. L.; Zimmer, R. Eur. J. Org. Chem. 2006, 4419-4428. doi:10.1002/ejoc.200600360

34. Saadi, J.; Reissig, H.-U. Synlett 2009, 2089-2092. doi:10.1055/s-0029-1217520

35. Saadi, J.; Lentz, D.; Reissig, H.-U. Org. Lett. 2009, 11, 3334-3337. doi:10.1021/ol901183h

36. Kunkel, E.; Reichelt, I.; Reissig, H.-U. Liebigs Ann. Chem. 1984, 512-530. doi:10.1002/jlac.198419840311

37. Reissig, H.-U.; Zimmer, R. Chem. Rev. 2003, 103, 1151-1196. doi:10.1021/cr010016n

38. Suzuki, A. J. Organomet. Chem. 1999, 576, 147-168. doi:10.1016/S0022-328X(98)01055-9

39. Molander, G. A.; Rivero, M. R. Org. Lett. 2002, 4, 107-109. doi:10.1021/ol0169729

40. Curran, D. P.; Wolin, R. L. Synlett 1991, 317-318. doi:10.1055/s-1991-34728

41. Miller, R. S.; Sealy, J. M.; Shabangi, M.; Kuhlman, M. L.; Fuchs, J. R.; Flowers, R. A., II. J. Am. Chem. Soc. 2000, 122, 7718-7722. doi:10.1021/ja001260j

42. Inokuchi, T. J. Org. Chem. 2005, 70, 1497-1500. doi:10.1021/jo0402529

43. Sadasivam, D. V.; Antharjanam, P. K. S.; Prasad, E.; Flowers, R. A., II. J. Am. Chem. Soc. 2008, 130, 7228-7229. doi:10.1021/ja802448x

44. Flowers, R. A., II. Synlett 2008, 1427-1439. doi:10.1055/s-2008-1078414

45. Seebach, D.; Prelog, V. Angew. Chem., Int. Ed. Engl. 1982, 21 , 654-660. doi:10.1002/anie.198206541 
46. Parmar, D.; Duffy, L. A.; Sadasivam, D. V.; Matsubara, H.; Bradley, P. A.; Flowers, R. A., II; Procter, D. J. J. Am. Chem. Soc. 2009, 131, 15467-15473. doi:10.1021/ja906396u

47. Haque, A.; Ghosh, S. J. Chem. Soc., Chem. Commun. 1997, 2039-2040. doi:10.1039/a705843h

48. Williams, D. B. G.; Blann, K.; Holzapfel, C. W. J. Org. Chem. 2000, 65, 2834-2836. doi:10.1021/jo9919005

49. Schwartz, A.; Seger, C. Monatsh. Chem. 2001, 132, 855-858. doi:10.1007/s007060170074

50. Williams, D. B. G.; Blann, K.; Holzapfel, C. W.

J. Chem. Soc., Perkin Trans. 1 2001, 219-220. doi:10.1039/b008110h

51. CCDC-789452 (for 17b) contains the supplementary crystallographic data. These data can be obtained free of charge form The Cambridge Crystallographic Data Centre via http://www.ccdc.ac.uk/data_request/cif.

52. Diamond software, 2.1d; CRYSTAL IMPACT, GbR: Bonn, Germany.

53. Dinesh, C. U.; Reissig, H.-U. Angew. Chem., Int. Ed. 1999, 38, 789-791.

doi:10.1002/(SICI)1521-3773(19990315)38:6<789::AID-ANIE789>3.0. $\mathrm{CO} ; 2-\mathrm{W}$

54. Berndt, M.; Reissig, H.-U. Synlett 2001, 1290-1292. doi:10.1055/s-2001-16051

55. Gross, S.; Reissig, H.-U. Synlett 2002, 2027-2030. doi:10.1055/s-2002-35599

56. Aulenta, F.; Berndt, M.; Brüdgam, I.; Hartl, H.; Sörgel, S.; Reissig, H.-U. Chem.-Eur. J. 2007, 13, 6047-6062. doi:10.1002/chem.200700057

57. Wefelscheid, U. K.; Berndt, M.; Reissig, H.-U. Eur. J. Org. Chem. 2008, 3635-3646. doi:10.1002/ejoc.200800293

58. Beemelmanns, C.; Blot, V.; Gross, S.; Lentz, D.; Reissig, H.-U. Eur. J. Org. Chem. 2010, 2716-2732. doi:10.1002/ejoc.200901455

59. CCDC-789453 (for 40) contains the supplementary crystallographic data. These data can be obtained free of charge form The Cambridge Crystallographic Data Centre via http://www.ccdc.ac.uk/data_request/cif.

60. Namy, J.-L.; Kagan, H. B. Nouv. J. Chim. 1977, 1, 5-7.

61. Girard, P.; Namy, J.-L.; Kagan, H. B. J. Am. Chem. Soc. 1980, 102, 2693-2698. doi:10.1021/ja00528a029

62. Imamoto, T.; Ono, M. Chem. Lett. 1987, 501-502. doi:10.1246/cl.1987.501

63. Molander, G. A.; del Pozo Losada, C. Tetrahedron 1998, 54, 5819-5832. doi:10.1016/S0040-4020(98)00272-5

\section{License and Terms}

This is an Open Access article under the terms of the Creative Commons Attribution License

(http://creativecommons.org/licenses/by/2.0), which permits unrestricted use, distribution, and reproduction in any medium, provided the original work is properly cited.

The license is subject to the Beilstein Journal of Organic Chemistry terms and conditions:

(http://www.beilstein-journals.org/bjoc)

The definitive version of this article is the electronic one which can be found at:

doi:10.3762/bjoc. 6.141 